\title{
Mucopolysaccharides in the Oral Mucosa of the Thyroidectomized Rat
}

\author{
Rodrigo Eisenmann Grimas \\ Loyola University Chicago
}

Follow this and additional works at: https://ecommons.luc.edu/luc_theses

Part of the Medicine and Health Sciences Commons

\section{Recommended Citation}

Grimas, Rodrigo Eisenmann, "Mucopolysaccharides in the Oral Mucosa of the Thyroidectomized Rat" (1962). Master's Theses. 1744.

https://ecommons.luc.edu/luc_theses/1744

This Thesis is brought to you for free and open access by the Theses and Dissertations at Loyola eCommons. It has been accepted for inclusion in Master's Theses by an authorized administrator of Loyola eCommons. For more information, please contact ecommons@luc.edu. (c) $($ ) $\Theta \Theta$

This work is licensed under a Creative Commons Attribution-Noncommercial-No Derivative Works 3.0 License. Copyright (c) 1962 Rodrigo Eisenmann Grimas 
MUCOPOLYSACCHARIDES IN THE ORAL MUCOSA

OF THE THYROIDECTOMIZED RAT

by

Rodrigo Eisenmasm Orimas

A Thesis Submitted to the Faculty of the Graduate School of Loyole Untversity in Partial Fulfillment of the Requirements for the Degree of Master of Science

June 1962 


\section{$\underline{\text { LIFE }}$}

Rodrigo Eisenmann Grimas was born on September 30, 1932, in David, Republic of Parama.

He attended Primary and Secondary school th Panama City and graduated from the Instituto Nacional Secondary Sahool in Jamuary, 1951. In Fobruary 1951, he entered the Untversidad Nacional Autonoma de Mexico Dental School and was graduated in July 1956 with the degree of Cirufano Dentista (Doctor of Dental Surgeny).

He went into private prectice in Panama Caty. Republic of Panama, from August, 1956 to August, 1960.

In September of 1960, We anrolled the Craduate School of Loyola Untversity to purswe a Mastor of Sctence degree th the Department of Oral Blology. 


\section{ACKNOWLEDGEMENTS}

The author wishes to express his deep and stncere gratitude to Dr. Patrick D. Toto for his guidence, patience, and understanding during the preparation of this thesis.

Acknowledgement is also made to Dr. John O'Malley for his decisive assistance with the photography.

The author is also tudebted to Mrs. Maria Gylys and Mrs. Damute Augtus for thetr work th the preparation of the histological sections.

To Dr. John A. Kollar, Jr. and Dr. Anthony W. Gargiulo my Brattude for thetr personal interest and friendly cooperation.

To my wife who gave me the necessary encouragement and affection my constant love and grattude. 
TABLE OF CONTENTS

Chapter

Page

I.

INTRODUCTION

1.

II.

REVIEW OF THE LITERATURE

2.

A. Comnective Tissue

2.

B. Thyrotd

21.

C. Thyroid influences in Connective Tissue

24.

III.

MATERIAL AND METHODS

29.

IV.

FINDINGS

33.

$\boldsymbol{V}$.

DISCUSSION

41.

VI.

SUMMARY AND CONCLUSIONS

51;

vin.

BIBLIOGRAPHY

53.

VIII.

APPENDEX

$60 ;$ 


\section{INTRODUCTION}

The different hormonal effects on the connective tissue have been subject to intense investigation. In the case of a deficiency of ctrculating thyroid hormones--hypothyroldism, it has been seen that changes in the loose connective tissue of shth does occur bringing the appearance of the pathological entity called myxedema. The shth of myxedematous patients has been studied by histochemical means, and it has been reported that the math disturbance is an abnormal accumulation of acid mucopolysacchartdes in the ground substance of the connective thssue.

It has been reported that thyroidectomy causes the appearance of myxedema in the shin of rats.

The loose comnoctive thsoue of the oral mucosa and of the skin are similar, and it could be expected that hypothyrotdism would cause a similar alteration in both sitse. However, the reports found in the dental literature about this condition are very limitted.

The purpose of this experiment is to study the oral mucosa of thyroidectomized rats with special attention to the mucopolysaccharide components of the connective tissue. 


\section{REVIEW OF THE LITERATURE}

A. Connective Tissue

Connective tissue is widely distributed th the body. Despite the fact that there are different kinds of connective tissue, with more or less special characteristics, all of them have certatn common features. Thus, the basic structural components are always cells, fibers, and the "ground substance".

Gromend Substance: The physicochemical state of the ground substance has been intensely studied. Electronmicroscopy, biochemical assays, histochemical and electrochemical methods have been used.

It has been stated $(24,25)$ that the ground substance is a heterogeneous colloid, largely formed of macromolecules of curbolyydrate-protein complexes (mucoproteins and glycoproteins) and mucopolyseacharides, that give at physiologle $p H$, an electronegattve charge. Thus the tissue exhibits the behavior of an immobile charged colloidal polyelectrolite, whose compastiton varios from tissue to tissue. Loose connective tissue, yields a low negattve charge, while very dense connecttve tissue such as bone or dentin shows a greator density of negatively charged colloid. Becouse of the negattve charge, the biological colloid gains unique properties affecting the water and salt distribution and the organic and inorganic cation bindings in the tissues (24). The role of connective tissue colloidal components in 2. 
influencing the diffusion and exchanges of electrolytes and other solutes is very important. It is now recognized that they are not fust an thert mass through which electrolytes and metabolites pass from the ctrculation to the cells (72). The distribution of diffusible ions is determined primarly by the indiffustble charged macromolecules of acid mucopolysaccharides and carbolyydrate-protein complexes (29).

According to Gersh and Catchpole $(28,29)$, the components of the ground substance are as follows:

Table 1.

Hyaluronic acid
Chondroith sulfate $A$
Chondroith sulfate $B$
Acid mucopolysaccharides Chondrotin sulfate C
Chondroith
Kerato sulfate
Heparith sulfate

Neutral heteropolysaccharides

Protein (a)

Probably of

Solluble collagen

local orlgin

\author{
Water \\ Bnzymes \\ Metabolttes \\ Immune bodies \\ Albumtn \\ Globulin \\ Vitamins \\ Hormones \\ Ions
}

Origtuating from plasma 
The ground substance consists of water soluble and water trooluble parts, which makes it a two-phase system: colloid-rich water-poor and water-rich colloid-poor $(28,29)$. Bondareff $(18)$ studies the ground substance with the aid of the electronmicroscope and described a system of vacuoles, with dimensions ronging from 500A to 2,000A, inclosed in a dense continum. The walls of the vacuoles are belleved to be rich especially in protetns, while the chilef constituent within the vacwoles is water. Gersh and Catchpole (29) stated that the components derived from plesma, in addition to those of local origin are thcorporated in this two-phase system. There is an equilibrtum state between the submicroscopic vacuoles and their walls, which in turn are in equilibrtum with the blood plasma.

The amount of wator of the connective tlesue deponds on the intribic hydrophilic properties of the colloid, colloidal charge densty, blood pressure, osmotic pressure of the blood plasma, lymphatic dratnage, etc. (29). With regard to the hydrophtlic properties of the collotd, Stack (72) considered that the water in comective tissue is bound to the mucopolysaccharlde-mucoprotetn-fibrous protein complexes. That, when connective tissue swells, there is an increase hydration of the ground substance and collagen flbers; the hydration of the ground substance preceeding the swelling of the collagen fibers. These changes in water binding seem to be inttiated by alterations in the ratio of free and colloid-bonmd electrolytes 
of the tissue. It has been demonstrated (41) that one of the components of the ground substance, hyalurontc acid, is strongly hydrophitic and has a defintte role in the water binding capacity of the tissue. The greater the amount of hyaluronic actd, the richer tn water the tissue is. Gersh and Catchpole (29) also report that the state of aggregation or polymerization of the ground substance is of primary importance for the accumulation of water in the tissues. The disaggregated ground substance is colloid-poor but rich in water; while the more highly aggregated ground substance is collotd-rich and water-poor.

Gersh and Catchpole (29) stated that the proporties and reactivities of the ground substance are the following:

a) It constitutes the actual enotronment of most cells of the organism. It is the "millieu meterteur" through which nutrients, metabolites, lons and water pass. The binding capacity of the ground substance makes it the great reservotr of water and tons and determines thetr relative concentrations in the cellular envtronment.

b) It is an important means of stabilizing the spatial relations of cells and tissues in organs and of matntainting them in functional relations.

c) It is the "mother liquor" from which are extracted the components of collagen and reticular fibers and the denser organic components of cartilage, dentine and bone. 
d) It is critically important in protecting the organism against bacterial envaston and certain forms of trauma.

e) It plays an important part in the changes developed duering growth and differentiation, regeneration, and aging.

f) It responds to hormones.

g) Its nature is altered in various pathological conditions: inflammation, rickets, periodontosis, scuryy, arteriosclerosis, and at least some of the collagon discases.

The mucopolysuccharide fraction of the ground substance (Table I.) has a great biological tmportance. Thetr escential components are hexosamine and haxuronic acti dertwattes of ether glucose or galactose. Glucosamine is a stable amino sugar dertoed from the replacement of a secondany hydroxyl (in the two-carbon position) by an amino group; while glucuronic acld is a monobasic acid, with an aldolyde remating at the opposite end of the straight carbon chath from the carboxyl sroup (70).

K. Meyer (54) suggests this classification for the mucopolysaccharides. Neutral: containing no acid groups (e.g. chitin: composed of acetylglucosamine only) 
Acid: a) simple: acid component, uronic atcd (e.g. hyaluronic actd: composed of acetylghucosamine and glucuronic actd) and

b) Complex: acid component, uronic acid and sulfuric or phosphoric acid (e.g. corneal mucoid, heparin: composed of glucosamine or acetylglucosamine, uronic actd and sulfioric acid; chondroith sulfioric actd: composed of acetylgalactosambre, glucoronic actd and sulfuric acid).

Hyaluronic actd: in 2934, Meyer and Palmer (57) isolated from bovthe vitreous humor, a high moleculer wetght polymer of a disaccharide, which consisted of equimolecular aceblylucosamtie and giveuronic acid. They named it "Hyaluronic acid". It was later also tsolated from umbilical cord (58), human shth (62), oral mucosa (71), et c. Pearce and Watson (62) have forond hyoluronite and chondroltin sulfate to be present th human skin in approximately equal amounts. However, Meyer and Chaffee (56) isolated $1.08 \mathrm{gm}$. of chondrodtin sulfate from the total mucopolysaccharide content of $1.85 \mathrm{gm}$. extracted from $2.28 \mathrm{hg}$. of frosh hog shth. Moyer found that hyaluronic actd wes the only mucopolysaccharide present in synovial fluid and vitreous humor, while it is absent in the comea and hyaltine cartilage.

Stacey (73) gtves this approxtmate values for the components of hyaluronic acid, extracted from different sources:

$\begin{array}{lcc}\text { Nitrogen } & 3-3.5 \% \\ \text { Glucosamtne } & 30-40 & \% \\ \text { Glucteronic actd } & 40-50 & \% \\ \text { Acetyl } & 8-12 & \%\end{array}$


From data on viscosity and streaming birefringence of flow, Blice and Snellman (14) estimated a mean particle length for purified zidtral hyaluronate of vetween 4,700 and 10,000 A. The highly asimetric chain is thought to be unbrenched. Hyahromic acid is polydisperse in nature, and tis particle sice and wotght depond upon the source and method of extraction, but a suggested molecular wotght was between 200,000 and 500,000 assuming a discechoride length of $10 \mathrm{~A}$. (7O). Rothman (70) stades that purified hyaluronic acid also has these qualities---_- is extremely hysroscopic: is not antigenic: and does not have $x-r a y$ diffraction and crystalline structure. Hyaluronic actd has no regular fiber structure under the electronmicroscope (38).

Meyer (50) considers that hyaluronic acld forms reversible polar complexes with protetn but is not chemically bound to it that at the phystologic pH of tisowes, hyalurowic acid is free of protein. Blis (23) and Ropes of al (67) have eupported this conception by electrophorectic studies of synovial flutd from cattle. Synovial flutd at $\mathrm{pH} 7.6 \mathrm{in}$ an electrical field has a fast mouthg polysaccheride componont which is separate from the two slower mouing albumin and globulm protein components. Ropes et al (67) compared the native symovial fluid with fluld that had been treated with trypsin in order to destroy the protein and liberate thy hyaluronic acid. They found no difference between the viscosity of the 
joint flutd before and after proteolysis and ascribed the viscosity enttrely to hyaluronic acid. Moreover, further addition of protein made no change in the viscosity.

However, Ogston and Statier (61) used ultra-filtration as a method of isolating the hyalueronic acid-protetn complexes from the foint flutd of cattle. They found that the fraction contatning hyaluronic actd was all within a sharply defined fillration separation and that all such samples contatined protein. Any attempt to separate the protetn consed degradation of the hyaluronic acid, as fudged by viscostly and ultracentrifugation. Thus, we can see that the relation of hyaluromic acid to the proteins of the ground substance is not clear.

Chondroitin sulfate: Chondroitth sulfuric acid has been found th a wide variety of connecthe thesues. Meyer and Rapport (59) found that cartilage, bone, cormea, corta, and the Itgamentum nuchas contatred chondroittn sulfute $A$. Chondrotth sulfate $C$ occurs in cartilage and also in umbilical cord, tendon and nucleus pulpusus. Chondrotth sulfate $B$ has been isolated from shth, tendon, heart cortic valves, and ligumentum nuchae.

Chondroltte sulfate on hydrolists yields sulfuric acid, acetic actd, givcuronic acid and chondrosamine (2-desoxy-2 ambrogalactose), combined in equimolecular proportions (70). Blix and Snellman (M) estimated that the mean particle length was about 4,700 A. with a molecular weight of the 
order of 260,000, from data on streaming birefringence. However, Mathews and Dorfman (50) extracted a chondroitth sulfate of high purity for a study of its physicochemical properties, and this material gave a moleculas wetght of 43,000 . It must be considered that the chondroitin sulfate is firmly bound to protelns and is very difficult to extract without altering its chomical and physical properties.

Meyer and Rapport (59) found that chondrolth sulfates from different tisous differ in spectic optical rotation, solubilly and resistance to encyme hydrolysts. Thus chondroith sulfate A from hyaltive cartilage is different from the bye $B$ from shin and the $C$ from umbilical cord and tendon. Chondroltin sulfate $B$ has on optical rotation of -60 degrees; ths calchum salts are less soluble than oither $A$ or $C$, and it is completely restetant to hydrolysis by testiculer or bacterial hyduronidase. Pearse (63) reports that the Chondrobin sulfate $A$ is lablle to testiculer and pneumococcal hyaluronidase, whith the chondrodth aulfate $C$ is lablle to the testlouler but not to the pmeumococcal hyaluromidase.

Chondrotth sulfate is very much lese viscous than hyoluronic acid and is thought not to play a significant role in the water binding of the connectlve tissue. The highly charged aniontc groups of chondroith sulfiric acid probably play a more important role in the binding or transfer of electrolytes (70). 
Chondroltin sulfate is firmly bound to nonfibrous proteins. Meyer (55) suggests that the chomaroith sulfate-protein complex contain about 35 to 40 per cent of carbolindsate. The protein is distinct from collagen and is castly digested by trypeth, with a relative high yleld of tyrosthe and uryptophane.

Chondroltin: This non-sulphated polysaccharlde appears to be an isomer of hyaluronic acid in whlch the D-glucosamine is roplaced by the D-gatactosamine. Libe hyaluronic acid, if forms viscous, solutions, gives a mucth clot on actdification and is digested by testiculer and bacteriat hyaluronidase. It has been isolated ouly from comea (72).

Keratosulfate: This is a sulfated mucopolyseccharide which is free of uronic acld. It is composed of equimolar amonats of N-acotylglucosambe. galactose and sulfate. It has been isolated from commea and rucleus pulposus (72).

Heparitu sulfate: This mucopolysaccharide fraction has been isolated from bovine aorta and from human amylotd tissue. It is composed of equimolar amounts of glucosamine uronic acid and sulfate and is reststant to testicular hyaluronidose (72).

Little is known of the chemical synthesis of the mucopolysaccharides. Mosbach and King (60) fod $C^{14}$ labeled glucose to gutrea plgs and formd that the carbon chain of gitucose ts directly avallable for converston thto 
glucuronic acid. Roseman et al (69) numbered a stratn a group $A$ hemolytic streptococcus which gtves a high yield of hyaluronic acid, in a medium in which was incorporated gitucose labeled with a radioactive carbon. It was found that glucose was the matn source of carbon for hyaluronic actd and also that the 1-carbon labeling was detectable in the glucosamtine yield on hydrolisis. Nothing is known of the mechanlsm of polymertation of the mucopolysaccharide complaxes, and there is no evidence that hyaluronidase plays wy part in synthests. There may, however, be entymatic control of polymerieation as this has been observed to take place th other biological systems, even extra-cellulerly, etther by addition or condensation (70). Histochemistry of the rround enbstence: The histochemical determination of mucopolysacchartdos is based on thetr motachromatic characteristics. When these substances are stathed with cortath strele-colored cationic dyes, they are capable of forming an enttrely differont color. Ehrlich th 2879 was the first to call this phomomonon 'metachromasta", the change in "colour". Among the ayes methyl violet, thionine, the atures and toluditise blue are the more commonly used.

Sylven (74) and Pearse (63) state that the reaction stgnifies only the presence of free electronegutive surface charges of a cortatn minimum density. It concerns many polyelectrolites and is not trdicative of any specific chemical compound. 
The substances (chromotropes) which produce metachromasia in antmal tissues are large macromolecular colloids, with spaced actilic groups, i. e. $-\mathrm{OSO}_{2} \mathrm{OH},-\mathrm{COOH}$ and perhaps $-\mathrm{OPO}(\mathrm{OH})_{2}$ to which the basic dye is fived (63). Sylven (74) considered the following factors as essential for the appear ance of metachromasia: a) An orderly alignment of the attached dye molecules. This is faoored tf the dye molecules have hydrophobic and hydrophilic parts. Meiachromasta wroolves two prtncipal steps: first the interaction between the dye and the substrate molecule and, secondly, mteraction between adfacent dye moleculos aggregated to the substrate. Sylven belicves that a molecule of water might be intercalated between the dye molecules, thus giving a hydrogen bond betwoen them. The presence of a hydrophillic part in the dye molecule, in a constant relation with the hydrophobic part, will fevored the orderly interaction of the dye molecules. b) The distribution of electro-negative surface charges of the substrate determbes the attaching altighont of the dye molecules and the degree of metacimomasta. A certatin mintmum tutercherge distance is a requisite for the reaction. The minimum distance ts estimated about $5 \mathrm{~A}$. The degree of metachromasia will therease when a highure aggregation of the attached dye molecules ts present, bringhng the intercherge detance to less then 5A. Statn is fwoored by high dye concentration and alkaltine $p H$ (thereastug hydration). c) The charge quality of the 
substrate also is important in the reaction. Thus, a sulphate radical will give an intenser reaction than a carboxyl sroup: d) The prosence of water is essential for metachromatic interaction: e) A cortati threshold of dye is apparentity necessary before motachromasia occur. Sub-threshold amounts of dye, in the case of the heparth for example, will produce orthochromatic aggregates. This quentilative abe-substrate ratio is important also because it has been observed that an excesstve amount of dye, will gtve a metachromatic substance, and orthochromatic appearance.

Sylven (74) considered that the spectrat absortion shif, or metachromasia, is dre to the now bonds appearing between adjecent dye molecules.

Rothman (70) considered that the substmees ordthorly showing metachromasia are large molecules of sulfate esters, such as mast cell heparth, chondrolth sulfates, and mucoltin sulfiric acid. Sylvon (M) demonstrated that hyahwonle acid, in ordor to show metachomasta, needs to be highly polymerised and in a minimum concentration of 1 per cent (w/vol.h in lower concentration, it gives on orthochromatiosreaction.

The histochemistry of polysacchartdes is closely linked to the ppriodic-acld Schiff reaction (PAS). Its use in hetology was first described by MCMewus (52) for the demonstration of mucin, but later Lille (47) and Hotchblss (40) elaborated the mothod into a histochemical one which could be used for the detection of different polysaccharldes in the tissues. 
Perlodic acid $\left(\mathrm{HIO}_{4}\right)$ is an oxidant, which breaks the carbon bonds (C-C) where these are present as 1:2-glycol groups (CHOH-CHOH), converting them into dialdehydes (CHO. CHO). The equivalent amino or alkylamino derivatives of $1: 2$ glycol or its oxidation product (CHOH. CO) are also attacked and converted into diahdehydes. The particular property of periodic acid is that it does not fiorther oxidize the resulting aldehydes, and these, then, can be localized by combination with the Schiff's reagent to give a substitute dye which is red th color (63).

According to Hotchitss (40), posttive results should be obtatned when the treated substonces fulfill the following requirements: al Contatiis the 1:2 glycol groupling or the equivalent amino or alhylamino derivative, or the axidation product CHOH.CO. b) Do not diffuse away in the course of tissue fication. c) Give an oxidation product which is not diffusible. d) Are present in sufficient concentration to gtoe a detectable color. Pearse (63), Hotchhiss (40), and other authors believe that the naturally occurring animal substances that glve a PAS posittve reaction are the monosaccharide, polysaccharide, neutral mucopolysaccharides, mucoproteins, glycoprotetus, glycoltpids, unsaturated lipids and phospholipids. Glegg et al (30) found that these complexes contatned as thetr main carbohydrate components, the hexose sugars glucose, mannose and galactose; together with the methylpentose sugar fucose and various 
hexosamtnes. All the mentioned authors agreed in the fact that acid mucopolysaccharides are not PAS positive. Also Braden (25) and Hoogwinkel and Smits (39), carried in vitro tests to demonstrate the PAS reaction of acid mucopolysaccharides. They found that chondroith sulfiric acid and hyaluronic acid, both were PAS negative. They noted that although the hexuronic acids were axidised, no aldehydes formation could be demonstrated.

There is a diffuse PAS staining in the connective tissues. Particular condensations are seen at the functions of comective tissue with epithelium and outside the endothelium of the capillaries (Basement membranes).

The treatment of the tissues with various enzymes will bring modifications in the results of the previously mentioned statnings. They could elther act by removing the reactive groups by hydrolysts, such as in the case of hyaluronidase and amylase with the consequent reduction in metachromasta and PAS or uncoverting reactive groups by breaking polysaccharide-protetn complexes such as in the case of proteolytic enzymes in which the more avallable carbohydrates will give a more intense result woth PAS.

The methods of fixation are of critical importance. The fixative could combine with some of the components of the tissue blocking the expected reaction. Also the presence of water soluble components in the 
ground substance must be considered in the case where a fixative in aqueous solution is used. In this case, the water soluble components will be washed out with the subsequent decrease in stainability of the tissue. Also, there could be a diffusion of the components of the ground substance to areas where they would not be present normally. The method of freezedrying avoids many of these complications. It respects more the general characteristics of the tissue and permits a better evaluation of the quantity and quality of the tissue components. This method of fixation consists of a rapid "quenching" of the tissue in temperatures of $-160 \mathrm{C}$., with a subsequent dehydration under temperatures of $-60 \mathrm{C}$. (63).

Fibers: The connective thsue contatns three kthds of fibers, collagen, reticulin and elastin that belongs to the group of fibrous proteins made up of elongated chains of amino acids joined together by the peptide linkage, the chains themsalves being held in more or less paraltel: alignment by various cross-linkages (70).

Collagon is the major component of the connective tissue. It is perhaps the most abuondant protein in the antmal kingdom. It has a relative high content of glycine and proline and accounts for practically all the hydroxyproline found in the body. This amino acid and also hydroxylystine seem to be formed after the molecule chatn has been assembled; the new amino acids are created by addition of hydroxyl griofips to some of the proline and lysine 
units in the chaten. This alteration of the primary molecular structure has not been observed th the synthesis of other proteins. Proltne and hydroxyprollne impart rigidily and stabiltly to the collagen molecule (35). Under the electronmicroscope, collagen shows a pertodictty of $640 \mathrm{~A}(35,43,47)$.

Collagen is synthesieed by the fibroblest. Actually, it is still not very clear whether these cells elaborate collagen fibers as such or a precursor. It seoms more probable that thoy elaborate a precursor that is deposited extracellularly and from which, by aggregation, the actual fiber is formed (4A). An alhall soluble, attrate soluble and an insoluble fraction of collagen have been discovered. Jachson (41) states that the alkall soluble fraction is the real precursor of the fiber and is the one that is symthesised indra-cellularly. It has been shown (41) that is the fraction that has a higher motebolic trcorporation of C14 labeled glyctic. The next aggreguted fraction ts the cilrate soluble which showes a lower C14 labeled glyctne motabollsm. Then, a series of cross-linkages, presumably th the $H$ bonding between the OH groups of hydraxyproline and the keto-imide groups of adjacent helices (36), makes it a mature insoluble collagen fiber. Rothman (70) states that pepsin digest collagen, while the action of trysin is not very clear. Soemingly, it produces, with difficulty, only mild changes in the collagen molecule.

It has been thought that mucopolysacchartdes are necessary agents 
for the formation of collagen fibers. Gross (34) shows the prectpitation of collagen fibers, in vitro, by chondrouth sulfate. Also it must be noted the fact of tncrease metachromasia before any vistble fiber can be observed th the case of wound healing. However, Wolbaach $(80,81)$ has demonstrated the formation in vitro of collagen fibers starthy from the neutral soluction of collagen and th the absence of mucopolysuccharides. We can see, therefore, that the role of mucopolysaccharides in fibrthogenests is still obscure.

Reticulten fibers charactortstically stain black with the silver impregnation mothod. It is known (45) that the basement membrane type of roticulin is composed of collagen fibers in very from association with a carbohydrate and a lipid componont. Only after hydrolysis is there a separation of these components $(48,79)$. It has also been shown (21) that antiglomerulus sonum rendered flourescent by the technique of Coons and Kaplan, stathed the bescomont mombrane fibers but not the collagen fibers, indicuting that an antigen not present in collagen is a component of reticulm. Robb-Smith (65) found that the extraction of this slices of human kidhey with a variety of solutions (dilute acetic acid, sodtum hydroxide) had a marked effect on the statining qualitios of the collagen fibers and reticultin fibers of gronulation tissue, but none on the reticulth fibers of the basement membrane. Therefore, the presence of two types of 
reticulin fibers has been assumed, one in granulation tissues and the other, the more "mature", in the basement membrane (s) (44).

Elastic fibers are scarce in the loose comective tissue. They appear as brilliant, highly refractive, cylindrical threads, much thinner than the collagenous fibers (51). Rothman (70) states that $x$-ray diffraction analysis of unstretched dastic flbers glves an amorphous pattern, in contrast with the orlented, fibrillar type, that gives collagen. An albuminotd, elastin, ts the characteristic constituent of these fibers. It is highly resistent to bollthg water, acids and alkalies. Elasth is slowly digested by trypstn, pep pepsin, and elastase (51).

Cells: The cells usually found in loose connective tissue are the: a)Fibroblasts which are the cells that enter into the synthesis and organization of the different fibers and ground substance. b) Undifferentiated mesenchymal cells; these are the cells usually arranged along the blood vessels, particularly capillaries and which some authors believe $(5 l, 62)$ have the pluoripotential copacity of becoming a new differentiated cell type such as on osteoblast or a fibroblast under the influences of certatn stimuil. Niezst cells, which are also found often in groups about the blood vessels. Thetr cytoplasm is filled with granules that are strongly metachromatic when stained with basic aniltne dyes. The presence of histamine and a heparin-like substance in thetr cytopiasm has been demonstrated (70). 
Thetr fronction as producers of ground substance, especially the actd mucopolysaccharide fractions, is the subject of intense investigation. Asboe-Hansen $(3,9,10)$ have postulated that they will respond to hormonal mfluences, eithor by troreasting in number and in grenulation, as in the case of TSH stimulation, or by losing thetr gremules and decreasing in number, as th the case of cortisone.

Also presont in the loose comective tissue are macrophages and a very small number of lymphoid wenderbing cells eostrophils, plasma cells, pigment colls and fat cells (51).

\section{B. Thyroid}

The secretions of the endoortne glands, the hormones, constitute a system for regulating the rates of growth, development and function of certath tissues and the rate of many metabolic processes within the body (26). All the glands of this complicated system work in a very close interdependence. They are subfect to control by the Central Nervous System, by other endocrine glands, by certain metabolttes or by a combination of these factors (51).

In this way, we can understand of the existence of the "PituitaryThyroid Axts". The secretion of Thyroid Stimulating Hormone (TSH) from the anterior lobe of the hypophysis causes an tncrease in the synthests and release of thyrotd hormones, and stimulates the growth of the thyroid 
gland. In the same way, an therease of ctrculating thyroid hormones in the blood, will 'ffed back", and reduce the rolease of TSH from the hypoplysis. A distrutton will bring about a greater release of TSH $(27,26,68)$. Stimulation of the paraventricular nuclet of the hypothalamus, has produced an increase in the amount of secration of TSH (38). However, it is not clearly mown, if the influence of the blood level of thyroid hormones has a drect action on the hypothalamus (20). By way of nouro-secretions carried through thot "Portal system", the hypothalamus will, in thern, stimutate the hypoplysis causting the release of byrotrophic hormones (26).

The Central Nervous system acts indirectly $3 y$ sogy of the hypothalamus. It is known $(28,56)$ for matonce, that changes of temperature, stress conditions, otc., will brtug alterations in the production and release of thyroid hormones.

The thyroid glend, develops from an epithetial budding on the floor of the primary oral canliy (64). It lies, with its attendant para-thyroid, on the lateral surface of the trachea, fust below the larymo. In the rat, if covers 4 to 5 trachoal rings. The two thyrotd lobes are fothed by an isthmas. The para-thyroid is closely applied to the antero-lateral surface of the thyroid (32). Each anatomical lobe of the thyroid is composed of a number of smaller structural lobes. Bach structural lobe conststs of mony lobules. These are made of a mumber of follicles bound together by 
fine connective tissue. The follicles are filled with a collotdal substance, matnly composed of thyroglobulth, lodothyroglobultn, mucoproteins and enzymes (27).

According to Plt-Rtvers (64), in the normal thyroid gland, synthesis of the hormone occurs in these stages: a concentration of lodide from the blood, b) Lodination of Tyrostne yielding mono and ditodotyrostne, c) conversion of these to Thyroxtne and Trilodothyrontne. Then, these Lodoamino acids are stored in the proteminyroglobulin. Later, after the hydrolitic action of thyrold protease, thyroxine and Triodothyrontine are secreted into the blood stream. Here agath, these lodoamino acids will be carried through the blood to the "torgot" thssues or cells. Ctrculating thyrotd hormones reach the extracelluler space of different organs according to thetr nature before they are picked up by the cell receptors. The efflciency of this last process varies in afferent organ, the liver being espectally active (66).

in order to discover the "active" form of the thyrotd hormone, thetr metabollc pathuays howe been intensely studiled (66). However, it is still not clear which metaboltte is the acting end-product.

The mode of action of the hormone is not clear etther. It is known that its presence brings an increase in the celluler metabolism, but the exact nature of its role has not been discovered. 
C. Thyroid Influence in Connective Tissue

As early as the the 189 's, thyroid extract began to be used in the treatment of hypothyroidism. And it was readily observed that the administration of this extract brought an immediate resolution of the cltnical symptom, so-ealled "myxedema". This term was used to describe the abnormal accumulation of mucinous substances th the dermal connective tissue. This was viewed as an example of a direct interrelation of the connective tissue and a hormonal action.

Byron (29) measured the fluid and electrolyte loss in subjects receiving thyroid extract. In the normal, there is more potasstum than sodium excreted indicating loss of intra-cellular fluid; while in the myxedematous subjects, an excess in sodium is evidenced that the accumulation of fluid is matnly extra-cellular. Brewer (16) in an autopsy study of hypothyrold subjects, reported the gross accumulation in the skin of metachromatic acid mucopolysaccharides. Asboe-Hansen $(2,3)$ and Asboe-Hansen and lversen $(7,8)$ stated that the tucreased actd mucopolysaccharide fraction in myxedema, as well as pretibtal myxedema and exophthalmus, was hyaluronic acid. They deprived hypothyroid patients of thyroid extracts, in order to make them myxedematous and found an accumulation of metachromatic material and of Ehrlich Mast cells. This metachromatic material was sensitive to testicular and bacterial hyaluronidase. 
They concluded that the accumulation of water was due to the water binding capactly of the hyalurontc acid. However, Watson and Pearce (77) carried out alkaline extractions of the interfibrilar muctnous matertal, of large spectimens of pretibial myscedema. They compared at with normals from amputated legs and reported an increase of both hyaluronic acid and chondroittn sulfute:

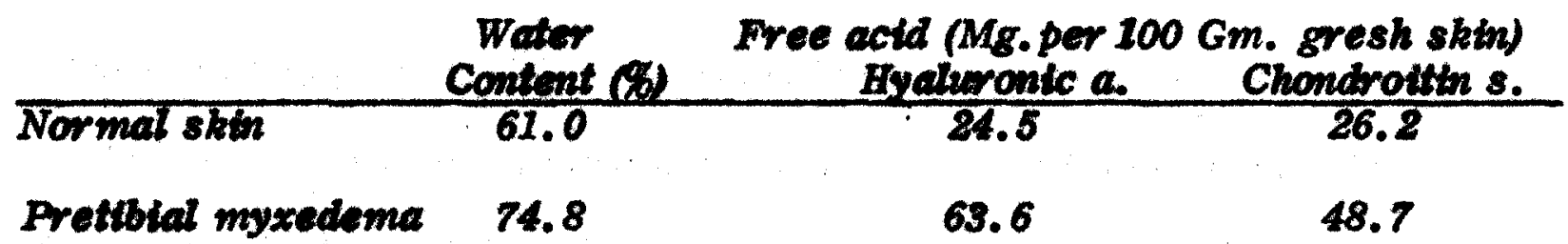

Ropes (67) also reported that the viscoslly of the joint fluid is increased in mysedema.

Asboe-Hansen $(5,6)$ reports in protibial myxedema, which he states can be present in hyperihyroldism as well as th hypothyroidism, a thickening of the shbi and in connecttve tissue, the accumulation of hyaluronate and chondroltin sulfate. He described signs of degeneration th the collagenous flbers as "btersting" apart, because of the muctnous edema. They also described the presence of Mast cells in the pertvascular areas and other parts of the comective thsuc. Feproposed that in these cases of localized myxedema, there might be an inoreased captllery permeability and a tendency to edema along with the thereased mucopolysaccharide formation. 
In generalized myxedema, he described similar changes, but less marked. Also, the sub-epidermal tissue exhibits increased metachromasia, in contrast with the circumscribed myxedema in which this layer is almost normal, and the mucinous edema is only present in the deeper layers of the corlum.

Astoe-Hansen (7) believes that the increased secretion of TSH is the necessary stimulus that will bring an elevation in the number of Mast cells and the liberation of thetr granules, thus causting an an end result, the greater amount of hyaluronic acid. He mfocted excesstve amounts of TSH in thyroidectomized (TX) gutnea pigs and reported the appearance of exophthalmus. Ludwig et al (49) injected ISH th normal and TX guinea pigs and foumd an therease th the amount of water and glucosaminecontatning sround substance in the TX gutnea pigs mfected with TSH; while the dry wetght of the tissuse both normal and TX remained the same. Dodds and Robertson (23) used dintiro-orthocresol in order to increase the metatolic rate of myxedematous tissues. However, in this case, coen though there was an increase in the metabolism, there was no reduction of the accumulated mucin in the ground substance. This was used by Asboe-Hansen as further evidence that the actual action of the thyroid hormones in the reduction of myxedema is by blocking the secretion of TSH from the pitutiory and not a diréct local one in the peripheral tissues. 
Del Conte et al (22) report biochemical assays and histochemical examinations of skin of TX rats, and thetr results show an increase concentration of the dermal acid mucopolysaccharide and also of Mast cells. Baume and Becks (11) worked with rats thyroidectomized at bbth, and ainong thetr findinus, report a decrease in the cellular and vascular components in the lamtna propia of the oral mucosa. This they belleved made the fibrous components more prominent. They reported that the greater changes were in the whelial structures, where the proliferation of germinal cells was slow, histodifferentiation retarded, and the life cycle of mature epthelial cells shortened. These facts, they believed, were responstble for the scaly skin and oral mucosa of hypothyroid rats.

However, Ziskin and Steth (82) using TX rhesus monkeys, described degenerative changes in the connective tissue of the oral mucosa, as well as in the epithelium. They found increased mitosis, hyperkeratosis, intercellular edema, and pyknotic nuclet in the eptiheltum. In the connective tissue, they found an increase in the cellular and vascular elements, coarsening and tickenting of the fibers with edema between them. They also mentioned, that "special stains" disclosed an trareased amount of mucous stating material and glycogen.

The occurrence of a pathological state, such as myxedema, in the oral mucosa, of of importance. Whether its loose, comective tissue is 
affected in hypothyroid conditions has wot been clearly studied.

The destre to evaluate, with histochemical means, this posstble alteration has prompted this investigation. 


\section{MATERIAL AND METHODS}

Thirteen male albino rats were used. Nine of these animals were thyro-parathyroldectomized by the commercial breeder in such a way that the Thyroid and Parathyroids were removed in toto at the age of four weeks. The animals were recetved in our laboratories a month later. The animals were fed regular Rockland Rat diet. They were sacrificed at the age of six to seven months by ether and then decapitated. The four control animals of the same strain were of appraximately the same age. The average weight of the TX antmals at the time of the sacrifice was $212 \mathrm{gm}$. , while the normal "control" animals had an average weight of $269 \mathrm{gm}$. Besides this difference of weight, no other vistble physical difference was observed between $T X$ and normal animals. The necks of the TX animals were preservea in $10 \%$ formalin and later a gross dissection was done in order to expose any posstble remnants of thyroid gland. No thyroid tissue was found.

specimens of tissue were obtatned from the oral mucosa of the cheek and vestibule and from the attached gingtva of the molar and incisor region. Also a sample of skin from the ventral surface of normal and TX rats was secured.

1. The Charles Rtver Breeding Lab. 
The majority of the specimens were treated by freeze-drying technique First, they were submerged in iso-pentane, pre-chilled with liquid nitrogen to -160 C., and later dehydrated for a period of four days at a temperature of -60 C. Other of the specimens were fixed for 48 hours in an acridineethomol solution, as recommended by Pearse (63) as a good method for the fixation and immobilization of actd mycopolysaccharides. A number of the normal and TX spectmens were fixed for ; 48 hours in an alcohol-acetic acid solution th order to obtatn sections for a better morphological study of the thave.

The ombeddthg was done th vacuo with Paraffin (Tissuemat Fisher Company) of a molting potut of $56.5 \mathrm{C}$., undor 25 pounds of pressure over a poriod of 15 minutes.

sections were cut from 6 to 10 microns. The thickest sections were used in encymo mewbation procedures, while the others wore used to observe clearly the call dofmition.

One group of the mounted slides were depar offinized with petroleum ather and then post-fiked th absolute alcohol overnight. Another series was deparaffinized th the following mawer: Immersion for five mbrutes each in two changes of Xylol; then five minutes in $100 \%$ alcohol, three minates in $95 \%$ alcohol and three mbrutes in 75\% alcohol. Finally, the sections were washed th distilled water for five to ten mbutes. All the tissuses fixed in 
alcohol-acetic acid solution and acridine-ethanol solution were deparaffthized in the second manner.

Two methods were employed for the demonstration of acid mucopolysaccharides. The ftrst was Tolutdine Blus at a concentration of 1:1000 and a pH of 7 (53), and the second was Thionten at a concentration of 5:100 and a pH of 7 (37). A number of sections thus prepared were mounted in water and axamined immediately while others wore monoted in Permount to preserve them for subsequent axamination.

Testicular Hyaluronidese troubation (Wyoth and Nutritional Blochemicals) was used for the removal of hyaluronic acid, chondroitin sulfate $A$ and c. The following procedire was used: A solution of a concentration of $1 \mathrm{mlg}$. of testicular hyaluronidase (approxtmataly $150 \mathrm{TRU}$ ) per 1cc. of Sorensen's Phosphate buffor at a pH of 7 was made. Five drops of the above solution wore used to cover sach deparaffinized stide. The slides werd placed in a Petri dish contatung a wet chamber and then meubated at $37 \mathrm{C}$. for three hours. Control slldes were treated with Sorensen's buffer solution alone and then treubated at the same temperature and for the same length of the. Immediately following incubation, the sections of both the normal and experimental animals were stained by ether the toluidine blue or thionth mothods.

For the demonstration of neutral polysaccharides the Periodic-acid 
Schiff (McManus modification of Coleman) method was used. Light green, a relatively non-specific plasmal statn was used as a counter statn (53).

Incubation in amylase for the removal of glycogen was also used in the following manner: A solution of a concentration of $1 \mathrm{mlg}$. of amylase (Nutrittonal Blochemicals) por 1cc. of Sorensen's Phosphate buffer at a pH of six was made. Five drops of the solution were used to cover each deparaffinized stide: the slides wore placed in a Petri dish contatning a wet chamber and then incubated for a period of 30 minutes at $37 \mathrm{C}$ of temperature. Control slides were treated with buffer solution alone and thoubated at 37 C for 30 mivutes. Immediatoly following incubation, the sections were statned with the periodic-acid schiff method.

In addition, sections were statned with Gomori stlver impregnation and Heidenhatr's Asan stath (modification of Mallory's connective ttsoue statnl to study the fibers components of the connective tissue. The first one to differentiate the argyrophilic reticulin fibers from the rose-colored mature collagen fibers; and the second mothod to have a general picture of the total content of the simillarly blue stained collagen and reticulin fibers. To study the general morphology of the tissues, sections were statned with the haematoxyltin and costn mothod. 


\section{FLNDINGS}

Toluidline Blue: No significant difference was observed in the epitheltum of both normal and $T X$ animals, regardless of the site from which the specimen was obtatned. The ruclei of all the epithelial cells statned metachromatically, with the muclet of the basal cell layer glving the most intense reaction. the The cytoplasm of the cells of the germinal layer; that is the basal and lower spinous layer, wewally gave an ordhochromatic reaction, while in the upper spinous and granular layer, an irregilar fabut metachromasia which thereased toward the superficial layers was observed. The presence of small metachromatic granules super imposed over the cells and the butercellular substance (ICS) of the granular layer was also observed. The keratin layer gewe a constant metachromatic reaction. The presence of a zone of lighter metachromasia in the begtuning of the kerattn layer was noticed. Morphologically, this zone corresponds to the Stratum lucidum. The thtercellular substence was observed to stath with a light metachromasta. This was always found in the upper sphous and granular layers; while th the germmal eone, tregular areas where the ICS was widened and without staining were also observed.

The basement membrane along the opitheltum and connective tissue junction did not stain in both the normal and TX animals. 33.

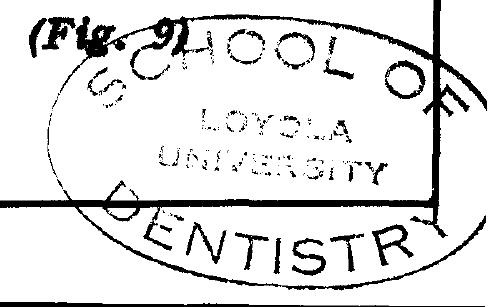


In the normal animals, the ground substance along the lamina propria presented a very light metachromasia. (Fig 1) Those areas where this staining reaction was observed uswally surrounded the cells. In addition, interfibrillar spaces, scattered around the lamina propria gave a light metachromaste. The comeotive tissue fibers were outlined by unstatied.

The muclot and cytoplasm of fibroblast gave a motachromatic reaction with the nuclat stathing more tutemaly. The presence of small metachromatic grenules wes observed the cytoplasm of some of the fibroblests. Mast cells were observed scattered throughoud the connecttve tisswe, but espoctally in the deoper submucosa leyers. These cells were filled with gremules that gave a very strong metachromatic reaction. (Fig. 7) The heavy concentration of these granules made it difficult to observe the tudfotdual cell dotall. Also, it was observod that the great density of srasules in some of the calls produced an apparent or thociwomatic reaction. Closer examination revealod that the epparent orthochromasta was due to impeded light transmisoton, through the dense mass of granules. A number of these cells wore found liberating thetr srowules into the ground substance. Those granules statnod tutensaly and brilliently motachromattc whon seen scattored singily within the ground substance.

Endothellal cells also guve a motachromatic reaction; the muclei were more tutense than the cytoplasm and were simillar, in this respect, to the 
flbroblast.

In the lamina propria of TX animals, a more intense metachromasta was observed as compared to the normal antmals. (Fig. 2) Large and more tutensely statned motachromatio areas were distributed th a random manur about the groumd substance. Such areas had a muctrous appear ance and contatned peorly outlined unstatned fibers. Moreover, in such areas, a groater collutarty was noted as compared to adjacent, less intensely stabied metachromatic areas. The predomtuant cell was the fibroblest, although Mast cells were also abuendant. The presence of small motachromatto grovules tberatod from the Mast colls mto the ground substance was also observed and were comperable to those seen the normal animal sectlons.

The stomabulty of flbroblast, Mast cells, and endothellal cells was stmiller in normal and TX cutmals. The only difference that was observed was the randombly distributed loct of thoreased mutachromasia in the ground substance of the Lamina propria.

The shin of normal animals domonstrate metachromasia in the ground substance of the subcutis. The growed substance in the subcutis of thyroddectomited animals showed distinctivily hoavier metachromasia than observed th the shin of normal animals. 
Thiontr: The metachromasta of the ground substance in TX animals was more intense then in the normal animals. However, it was evident that the overall degree of motachromasta obtatmed with the method was proportionally greater for both normal and $T X$ animals than that obtatned when Toluldine Blwe was used. Apart from this therease in motachromasia in The ground substance the cellular components of the lamine propria stathed in the same monnor as with the toluidtre blue mothod.

Testioular Hyaluoronidase: is normal and TX antmals, a roduction in mothotromasta of the ground substance was observed folloning inowbation for three hours with Als aneyme. (Fige. 4 and 5)

It was notlecd that the model control sildes of TX and normal animals incubatod in buffor solution alow showed a reduction in motachromasta. Thie reduction was not as great as the one observed th the soctlons boubated w buffer plus ensyms. Aftor troatmont of the tisewes with this eneyme, only a slight motncliremaita rematrad in the ground substance.

The metadiromatic reaction of the Mast colls granules, fibroblast and endothallal calls in TX and normal animals was not altered by enzyme treatment. Morecuer, the gravules Iberated from the Mast cells buto the ground substence matulatwed thetr same tutense metachromasta. 
The metachromasia found in the different epithelial components was not removed by testieular hyalueronidase.

Periodic acid Schiff There was no significant difference in the characterLtics of PAS statwabllty between the normal and TX animals.

In both groups, the only PAS positwe area found in the epitholsum was the tutercellular substance recognisable with all the epthelial layers as a thin red the that dicappeared in the horatin layor. The muclet and cytoplasm of all the epithollal celle were PAS negative. Whon light greon was weed as counter statn. the epinolial cell ruclet and cytoplas $m$ would accept the counter stath. The hrrath layer was aloo PAS nogative and consistently could bo stained sroen.

By virtue of the wids dotribution of aunilable reactive polysaccharides, the comective thawe in both normal and TX animals geve a stmilor coerall PAS positive reaction. In some areas, probably because of a greater thlekness of the section, the PAS reaction was more intense.

The basemont membrans botween the optholtum and connectloe Hsoue and around capllterles stabned very strongly PAS positue. (Fig. 8)

Mast cells cytoplasm were fulled with amall PAS posittve graules. (Fig. 6) Some of these gramules could be ebserved scattored in the ground substance. Occastonally, the thit cytoplasm of some of the fibroblast could be observed; and they libewlse showed a PAS posthte reaction. The 
38.

presence of small red statning granules in thotr cytoplasm sometimes could also be observed. Endothelial cells statned PAS negative.

Amylase: Bncubation with this enxyme did not modify the characteristic of PAS statrabituly of the epitholium thether the normal or TX antmals. The intercelluler substance conthousd to be the only PAS positive area present in the eptithaluem.

The basemont membrane did not vtsibly undergo modification following amylase tucubation. It tutense PAS postive reaction rematred the same.

The ground substance of the amylase treated spectmons statred stimitlarly to the model control stides, in both TX and normal animals. However, th was observed that after tmmersion th the buffer, with or whthout ensyme, the sections stathed slightly less butensely than those stathed without tmmeraton in the buffer solution.

It was obsorved that aftor moubation with amylase, there was a loss of PAS posttwe granules from the Mast cell and fibroblast's cytoplasm. This was specially noticed th the Mast cells from the tissue specimons of TX antmals. As a result from this encymatic action, the Mast cells took a fadod appearance makting ut more difficult to examine.

Gomori stlver impresnatton: Along the basement membrane folntong the epithelturn and conmective thowe and around blood vessels, the presence of 
argyrophilic fibers was constantly observed in both normal and $T X$ antmals. (Fig. 10)

In the lamtua propria and deeper layers of the connective thesue, mumerous rose-colored, mature collagen flbers were seen arranged in an irregular and intricate pattern. Thls finding was also similar in both normal and TX antmals.

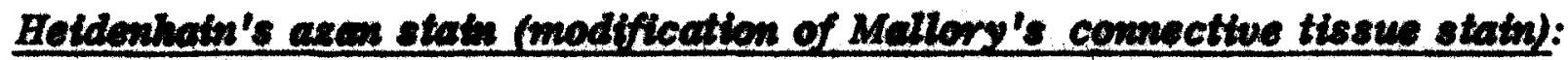

An thense and rogularly distributed blue staln was observed all over the thtercellular spaces of the connective thesuc, contrasting markedty with the red-statned calls and muscle fibers. Both roticulin fibers th the basement membrane and collagen fibers in the lambu propria stath with the same intenstly, therefore, could not be individually ldentified with this mothod. The sections from normal and TX animals presented similar stabing characteristics.

Hacmatasylin and costn: The opthelium of the oral mucosa consisted of the usual basal, spinous, gramilor and horatin layers. The thichness of these layers varied th the different areas of the mouth, depending upon whore these specimens were taken (e.g., The horatin layer th the masticatory mucosa is wider than in the lining mucosa). Regular intercellutar spaces were observed along all the epithellal layers. The mitotic figures observed in the germtnal layers of the epthelium of normal and $T X$ animals 
were not found to be measurably different. The epithelium of TX and normal animals presented in all aspects, similar morphological characteristics.

The presence of filoroblast, Mast cells and macrophages were observed in the commective tissue. The overall number of these celts was similar in TX and normal animals. The absence of inflammatory cells in both normal and $T X$ animals was strikting.

The ground substonce had an homogenous appearance and contathed capillartes stmitor in number and structure in both normal and $T X$ animals. 


\section{DISCUSSION}

The histochemical methods generally used for the detection of acid mucopolysaccharides are based on the observation of the metachromatic shift that basic dyes axperience when in contact with compounds with a net electrical nogattue surface (63). It has been clearly demonstrated that chondroith sulfuric acid, hyalueronic actd and hepar in statn metachromatically. A differentiation between these actd mucopolysaccharides can be done by thetr thcubation with ensymes which will react specifically with some of them only. Thus testicular hy aluoronidase will only hydrolite hyaluronic actd and chondrotth sulfuric acid $A$ and $C$; while hepar th and chomdroltth sulfiritc actd $B$ will not be affected (63). Subsequent statuing of tissues contatuing such componends can gtve ws a picture of the localization and estimated amovent of these substances th stu.

Braden (15) and Hoogwtwhel and Smits (35) have clearly demonstrated that acid mucopolysaccharides do not stain positive with the PAS mothod. Only neutral polysaccharides statn posttwely with this method. This offers us the opportienity to differentiate between neutral and acid polysaccharide tissue components, the actd mucopolysaccharties statinting only metachromatically and the neutral polysaccharides PAS posittve. If the tissues are 41. 
incubated with a spoctflc enzyme, such as amylase, which removes the PAS posittve glycogen, a further differentiation of the neutral polysaccharide fractions can be made. After tncubation, only the remaining PAS positive fractions, such as glycoprotetns, mucoproteins, and glycolipids will be statned. Therefore, the presence can be determined and an estimate made of the amount of glycogen th the tissue.

Watson and Pearse (77) demonstrated the extstence of chondroitin sulfate and hyaluronic actd th normal sktn; whils Schultz-Haudt (71) in a comprohonstve study asserted the existence of these acid mucopolysacehasties in normal oral mucose.

It is known that thyrotropic and thyroid hormones may have a direct action upon the cennective tissue. In the case of hypothyrotdism, one of the symptoms is the cecumulation of abnormal amounts of a muctnous substance on the comnective tiesue of the shin of hypothyrotd subjects. This pethologtcal entily was donombatod "myxedema". Watson and Pearse (77) studied the skin of myxedematous patients by bioehemical assays and demonstrated that the muctnous substance was due to an trorease in hyalueronic aold and chondrotth sulfiertc actd. Asboe-Hensen $(2,3)$ also demonstrated htstochemically an morease of these substances th the sktn of myxedematous human subfects. Asboe-Hensen clatmed that the larger quantity of actd mucopolysacchartde was hyaluronic acid. In the case of generalized 
myxedema, this accumulation was found along the lamina propria while in pretibial myxedema, it was found th the deeper layers of the connective tissue. Asboe-Hansen (4) also described an tncrease of the mast cell population in these myxedematous areas and proposed the theory that these cells under the fufluence of TSH were responstble for the greater production of hyaluronic actd.

Del Conte et al (22) exambred with biochemical and histochemical methods the skin of TX rats and reported fudings stmiler to those described by Asbos-Honsen th the skth of hypothyroid humans; that is, the accumulation of metachromatio acid mucopolysaccharides and Mast cells in the connoctive thsers. The fludings of Del Conte are supported by our observaHows of thereased motceluromatic mucopolysaccharides in the subcutis of our thyrotdectomited rats.

Asboe-Hensen also belleves that the Mast cells are solely responsible for the production of all the around substance on the connective tissue. This concept has been fustifiedly attacked by $K$. Moyer (54) and Rothman (70) among others. Sylven (75) pothated out the difficulty for the proposed chemical re-structuration phenomena, that would have to occur th order to change the hepartn contathed in the Mast cells to the hyaluronic acid and chondroltin sulfate present in the ground substance. Also the overall number of Mast cells th the connective tissue does not seem to correlate 
with the large content of ground substance. There are areas in the body where, in spite of the presence of large amounts of ground substance, no Mast cell can be observed. Furthermore, the flbroblasts, the most abundent cells in loose comective ilsoue, react simillarly to the Mast cell by Mistochemical statuting asserting the butracellular presence of noudral and actd polysaccharldes make the idea of Mast cells as sole producers of ground substence, guite unaccoptable.

The study of the comectioe thesue of the oral mucosa of normal and TX rate was carried on with the help of hetochemical and histological mothods simillor to those empleyed by Asbos-Hansen, Del Conte and others for the dotection of acti mucopolysaccharides, notiral polysaccharSiles and fibors components.

The most importent finding was the incroased motacluromasia of the sronend substance th the lam tha propria of TX animals. This was demonstrated with both toluidine blue and titonin staining methods. This result glves support to the proviously reforted horeased metachromasia in myxedematous skth, thus suggesthe chomical alterations in the oral mucose due to a decrease in the ctrculating thyroid hormones. However, in splte of this modifieation in the sround substance of $T X$ animals, there were no observable clintod changes, swok as ulcerations, desquamations, pufftucss, etc., th the oral mucosa of TX aulmals. Thetr oral mucosa 
had a macroscople appearance simiter to that h normal animals. Andersen and Asboe-Hansen (1) reported similar findings in nearly one hundred cases of hypothyroldism in humass. Even though the clinical picture of myxedema was absent, the shin showed more metachromasia then normal. Seemingly, there exists a droct relation between the state of hypothyroidism and the local accumulation of acid mucopolysaccharldes in skin and oral mucosa. The spectal conditions that canse the appecrance of the clinically vistble myxedema in some cases and not bothers are not known.

The decrease in motachromasta of the ground substance of the oral mucosa after incubation in testiculer hydiuronilase auggests the prosence of acid mucopolysacchartes of the ordar of hyaluronic actd and/or chondroith sulfirtc acid $A$ or $C$. Poarse (08) stated that the chondroltin sulfate $B$ is not hydrolized by this ensyme. The fact that some light

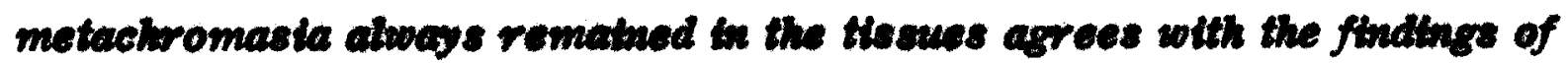
Schults-Houdt (71) whe stated that the testeular hyalurouldase resistant chondrodth sulfate $B$ to present in the combettoe tiesue of the orat mucosa of man. A similler finding was observed with the metachromatic granules of the Mast cells. Nows of the intra or extra-celluiar granules were affected by this enxyme. They statnod th the same way before and after moubation with testicular hyaluronidase. The granules are, therefore, composed of a substance difforent than hyaluronle acid and chondroith sulfate $A$ or $C$. 
In fact, it has been shown that the substence responsible for the strong metachromasia of Mast cells is heparth. In this regard, it is diffleult to accept the idea that in myxedema the increased actd mucopolysaccharide content of the ground substance is the by-product of the heparin derived from the Mast cells. There was no observable tncrease th the overall number of Mast cells th the oral mucosa of $\mathrm{TX}$ rats. Mast cells are very abundant in the rat and we found a great number in the oral mucosa of normal animals. There were areas, especially in the deeper layers of the connective thave, that showed mtense Mast cell population th both normal and TX andmals. Asboe-Honson and Del Conte did not employ any prectse method of Mast call count in shth; therafore a quantitative statement about the number of these cells ts undeliable.

There were areas of the sround substance, especially along the Lamba propria of the attached gtagtiva, that gowe a metachromatic reaction and to solich the only cell available was the fibroblest. The cytoplasm of fibroblasts stath metachromatically. This fact suggests the direct participation of fibroblasts the the elaboration of the acid mucopolysaccharides components of the Erovond substance.

There was a very trregular pattern of distribution of exeas of strong metachromasia in the connoctive tissue of $T X$ animals. The reason for this random concentration of actd mucopolysaccharides th the thswe is not 
known.

The results obtatned with the PAS method showed no signifficant difforence in the ground substance characteristics between the normal and TX animals. This suggests the presence the tissues of both antmals of similar amounts of reactive carbohydrate groups and also of their presence in a stmilar state of asgregation.

Engel (24) and Gersh and Catchpole (28) stated that an elevation in the water content of the tissue will cause a reduction in the intensity of the PAS reaction. Thoy belleve that the greater dispersion of tissue polysaccharides in a gtven area, couse by edoma, will reduce the number of reactive grouts avatlable for the PAS to stath. However, the tissue specimens from the TX antmals stathed with the same intensthy as that obtained from normal animals. This suggests the absence of edema th the connective tissue of the oral mucosa of $T X$ andmals.

The theubation of the tissues from normal and $T X$ animals in a buffer solution followed by the PAS stath ald not bring any stgnificant reduction in the intensity of the reaction. This tralloates that the greater number of hatoropolysaceharide complexes in the connective tissue of a normal rat are, beccuse of thetr state of aggregation, of a water insoluble nature; and, the same maner, that thyroldectomy did not cause modifications observable with the methode used by us. 
The Mast cells were observed to statn positive with the PAS and metachromatic methods; therefore, we can assert the presence th these cells of neutral and actd polysaccharides. Similar results were obtained th the fibroblasts. This supports the concept that both fibroblast and Mast cells play an important role in the production of ground substance.

The most intoresting result observed after the fucubation of normal and TX thesue spectmens in amylase inas the marked hydrolysis of many of the PAS posttwe gramules present the cytoplasm of Mast cells. This was more culdent th the Mast cells of $\mathrm{TX}$ specimens. The remaining PAS postive substances in the cytoplasm of Mast cells are heteropolysaccharides of a different nature than glycogen. The larger content of glycogen th the Mast cells of TX animals might be related to their greater production of groumd substance. Mosbach and King (60) and Roseman et al (69) have demonstrated that glucose can be used as a primary structural unit th the oyntheste of actd mucopolysaccharidos. The role of Mast cells th the symthests of actd mucopolysaccharides has been discussed by Asboe-Hansen. However, he belleves that the production of hyaluronic acid is by way of a hepartin-like precursor. Sylven (75) stated that from a chemical and structural potat of view, th is very unilhely that this change would occur. But, if hstead of a heparth precursor, giycogen is utilized, as suggested by Mosbach and King (60) and Roseman et al (69), the role of Mast cells th 
the symthesis of acid mucopolysaccharides could be more easily understood. The higher content of glycogen observed th the Mast cells of TX animals, suggest the possibility of their increased symthesis of acid mucopolysaccharides. However, it could be attributed also to the intra-cellular retention of larger amounts of gilycogen, because of low motabolic requirements.

The basement mambrane along the epttheltum and connective tissue fronction appeared stmiltar in both normal and $T X$ tissue spectmens. It was observed that the matn constutuents of thes particular zone were the roticulin fibers and the PAS pasitive glycoprotoins. It was interesting to notice that the basement menbrane did not show any metachromasia Indicating the absence of actd mucopolysaccharides in thts particular sone.

No sienfficent difference was observed with the Gomori stlver impregmation and the Hoddenhatn's axan statn mothods in the collagen components of the connective tissue of normal and thyroidectomized animals. The fibers were observed to be normal in number and structure in the oral mucosa of TX rats. This finding is contrary to the Ziskth and Stein (82) report of collagen degeneration in the oral mucosa of TX Rhesus monkeys. An interesting observation was the absence of inflammatory calls in the connective tissue of TX animals. The cellular components of both normal and $T X$ antmals were observed to be similar. This finding is contrary to the report of Baume et al (11) who found a reduction in the cell 
population of the connective tissue of the oral mucosa of TX rats.

The epitheltum of the oral mucosa of normal and thyroidectomized animals did not show any significant difference with any of the methods used. We were not able to observe any degenerative changes in the epithelium of TX animals, as was reported by Baume and Ziskin and Stein.

The only deftnite alteration that was brought about by thyroidectomy was the increase accumulation of actd mucopolysaccharides, especially the hyaluronic acid type the ground substance of the comective thssue of TX antmals. No other stgns of pathology were detectable in the thssues under study, with the methods used by us. 


\section{SUMMARY AND CONCLUSIONS}

An experiment to study the possible alterations of the connective thssue in the oral mucosa of thyroddectomized rats was done. Special attention was given to the study of the mucopolysaccharide components of the Eround substance of the connective tissue. A comparative evaluation of the oral mucosa from TX and normal animals was done.

Thtrteen male alb tro rats were used. Nthe of these animals were Thyro-parathyroddectomized at the age of four woeks, while the rematning four normal mimals were used as control. The animals were sacrificed at the age of seven months.

Tissue spectmens were obtained from the oral lining and masticatory mucosa and skth. The tisines were treated by either the freeze-drythg method or alcohol-acetic acid and acridine-ethanol ficative solutions.

Different histochemical stainings for the determination of mucopolysaccharides wore used: Tolutdine Blue, Thtonin and PAS. Also, the following histological methods were used to study the fiber components and genoral morphology of the connective tissue: Gomori stlver impregnation, Heldewhatn's azcon stain, and haemataxylin and cosin. Enzyme incubation in Testicular Hyalurondiase and Amylase was also done. 
The results lead us to the following conclusions:

1. Thyroidectomy causes alterations in the comnective tissue of the oral mucosa of the rat similar to those that have been previousiy described in skin. This alteration was in the form of a moderate increase of acid mucopolysacchartdes, espectally hyahuronic acid, in the ground substconce of the connective tissue of TX rats.

2. The oral tissues did not present any clinically visible sign of "myxedema".

3. There was a greater content of amylase removable glycogen in the Mast cells of TX Animals than in normal animals. 
1. Andersen, H., Asboe-Hansen, G., and Quaade, F., (1955) Histopathological Examination of the Skin in the Diagnosis of Myxedema in Children, J. Clin. Endocrinol. 15: 459.

2. Asboe-Honsen, G. (1950) The Variability in the Hyalueronic Acid Content of the Dermal Comective Tissue under the Influence of Thyroid Hormone. Acta Dermat. -venereol. 30:221.

3. Asboe-Hansen, G. (1950) The intercellular Substance of Connective Tissue in Myxedema. J. Invest, Dermat. 15: 25.

4. Asboe-Hansen, G. (1959) Endocrine Control tn Connective Tissue. Amer. J. Med. 26: 470.

5. Asboe-Hansen, G. (1960) The Pathogenests of Cutaneous Myxedema. AMA Arch. Derm. 82: 32.

6. Asboe-Hansen, G. (1958) Hormonal effect on Connective Tissue. Physiol. Rev. 38: 446.

7. Asboe-Hansen, G., and versen, K. (1951) influence of TSH on Connective Tissue. Acta Endocrinol. 8:90.

8. Asboe-Hansen, G., Iversen, K., and Wichmann, R. (1952) Malignant Exophthalmus: Muscular Changes and Thyrotropan Content in Serum. Acta Endocrinol. 11: 346 .

9. Asboe-Hansen, G., et al. (1959) Tissue Edema. A stimulus of Connective Tissue Regeneration. J. Invest. Dermat. 32: 505.

10. Asboe-Hansen, G., and Wegelius, $O$. (1956) Mast Cells and Tissue Water. Exper. Cell Res. 11: 437.

11. Baume, L. J., and Becks, Hermann (1952) Effect of Thyroid Hormones on Dental and Paradental Structure. Para dent. 6: 89. 
12. Barbee, F. E. (1960) Histochemical Demonstrations of Some Protetn Substances in Mucodal Eptthelia of Rats and Man. Thesis. Univ. of IIl.

13. Blix, G. (1940) Studies in Glycoproteins. Acta physiol. Scandinav. 1: 29 .

14. Blix, G., and Snellman, O. (1947) On Chondroitin Sulfuric Acid and Hyalueronic Acid. Chem. Abstr. 41: 2260.

15. Braden, A. W. H. (1955) The Reactions of Isolated Mucopolysaccharides to Several Histochemical Tests. Stain Tech. 30: 19.

16. Brewer, D. B. (1951) Myxedema: An Autopsy Report with Histochemical Observation on the Nature of Mucotd infiltration. J. Path. and Bact. 63: 503.

17. Brown-Grant, K. (1957) The "Feed-Back" Hypothesis of the Control of Thyroid Function. in CIBA Fonendation: Regulation and Mode of Action of Thyrold Hormones. Colloquia on Bndocrinology. Boston: Little Brown and Co. p., 97.

18. Bondareff, W. (1957) Submicroscopy Morphology of Connective Ground Substance with Particular Regard to Fibrillogenests and Aging. Gerontologia. 1: 122.

19. Byron, F. B. (1934) The Nature of Myxedema. Clin. Sc. 1: 273. 20. Courrier, $R$. (1957) Contributions to the Regulation of Thyroid Activity. In CIBA Foundation: Regulation and Mode of Action of Thyroid Hormones. Colloquia on Endocrinology. Boston: Little Brown and Co. p., 21.

21. Cruikshanks, S. and Hill, A. G. S. (1953) Histochemical Identification of Connective Tissue Antigen. Nature of Structures of Collagen: Papers... Edtted by J. T. Randall, London: Butterworth. P., 27.

22. Del Conte et al. (1955) Effect of Thyroidectomy, Thiurea and Iodine on the Dermal Acid Polysaccharides and the Mast Cells in Rats. Acta Endocrtnol. 20: 343. 
23. Dodds, E. C., Robertson, J. D. (1933) The Clinical Application of Dinitro-O-Cresol. II A Study of Myxedema. Lancet 2: 1197.

24. Engel, Milton. (1958) Integrated Behovior in Connective Tissue. Oral surg., Oral Med., Oral Path. 11: 724.

25. Engel, M., Joseph, N., Laskin, D., Catchpole, H. (1960) A Theory of Connective Tissue Behavior: Its Implications in Periodontal Disease. Ann. N. Y. Acad. Sci. 85: 399.

26. Fulton, J. F. (1955) Textbook of Physiology. Seventeenth Edition. W. B. Saunders Co., Philadelphia and London.

27. Gardner Textbook of Anatomy.

28. Gersh, I., Catchpole, H. (1949) The Organization of Ground Substance and Basement Membrane, and its Stgnificance in Tissue Infiery, Disease, and Growth. Am. J. Anat. 85: 457.

29. Gersh, I., Catchpole, H. (1960) The Nature of Ground Substance on Connectlve Tissue. Persp. Biol. and Med. 3: 282.

30. Glegg, et al. (1954) Presence of Carbohydrates Distmet from Acid Mucopolysaccharides in Connective Tissue. Science. 120: 839.

31. Greer, M., Yamada, T., Itho, S. (1960) The Participation of the Nervous System th the Control of Thyroid Function. Ann. N. Y. Acad. Sci. 86: 667.

32. Greene, E. (1949) The Rat in Lab. Invest. Ed. Parris and Oriffith. J. B. Lippincot Co. P., 36 .

33. Gross, J. (1948) Electron Microscope Studies of Sodium Hyaluronate. J. Biol. Chem. 172: 511.

34. Gross, J. (1956) Behovior of Collagen Units as Model in Morphogenesis J. Biophys. Blochem. Cytol. Supp. 2 (Part 2): 261-280.

35. Gross, Jerome, (1961) Collagen. Seientific Amer. May. W. $H$. Freemen and Co.

36. Gustavson, K. H. (1956) The Chemistry and Reactivity of Collagen. Academic Press, New York. P., 342. 
37. Gurr, E. (1959) Methods of Analytical Hystology and Histochemistry. Baltimore. Williams and Wilkins Co.

38. Harris, G. W., Woods, J. W. (1957) Hypothalamus-Pituitary-Thyroid Relationshtps. In CIBA Foumdation. Regulation and Mode of Action of Thyroid Hormones. Colloquia on Endocrinology. Boston: Little Brown and Co. p., 3.

39. Hooghwinhel, C. J. and Smits, G. (1957) J. Histochem. Cytochem. 5: 120 .

40. Hotchkiss, R. D. (1948) Arch. Blochem. 16: 131. A Michrochemical Reaction Resulting in the Statining of Polysaccharide Structures in Fixed Tissue Preparations.

41. Hvidberg, E. (1960) Water binding by:Comective Tisssue and the Acid Mucopolyseccharides of the Croumd Substonce. Act. Pharmacol. 17: 267.

42. Ingbar, S. H. (1960) The Interaction of the Thyrold Hormones with the Proteins of Fumon Plasma. Ame. N. Y. Acad. Sci. 86: 440.

43. Fution Jackson, S. (1957) Structurial Problems Associated with the Formation of Collagen Fibrils in Vivo. in Council for international Organication of Medteal Sciences. Connective Tissue Sympostum. Springfleld, Charles C. Thomas.

44. Jackson, D. S. (1958) Some Blochemical Aspects of Fibrinogenesis and Wound Healing. New England J. of Med. 259: 814.

45. Kramer, H., Little, K. (1953) Nature of Reticulin. Nature and Structure of Collagen: Papers.... Edited by J. T. Randall. London: Butterworth. p., 33.

46. Kulonen, E. (1954) Recent Advances in the Chemistry of Collagen: in G. Asboe-Hansen, "Connective Tiseue in Health and Disease". Copenhagen, Munksgaard.

47. Litlie, R. D. (1947) Reticulin Staining with Schiff Reagent After Oxidation by Acidifred Sodium Periodate. J. Lab. Clin. Med. 32: 910. 
48. Little, K., Windrum, G. $M$. (1954) Lipid Component of Reticulin. Nature (London) 174: 789.

49. Ludwolg, A. W. , et al. (1950) Role of Mucopolysaccharides in Pathogenesis of Experimental Exophthalmus. Proc. Soc. Exper. Biol. and Med. 73: 137.

50. Mathews, M. V. and Dorfmen, A. (1952) The Molecular Weight and Viscosity of Chondroitin Sulfiertc Acid. Arch. Biochem. 42: 41.

51. Maximow and Bloom Textbook of Histology. (1954) Philadelphia and London. Sixth Edition. W. B. Sander Co.

52. McMarute, J. F. A. (1946) Histological Demonstration of Mucin after Periodic Acld. Nature, London. 158; 202.

53. Manual of Histologic and Spectal Stathing Technics. Second Edition. New York, McGraw-Bill-Blakiston Co.

54. Meyer, K. (1945) Mucolds and Glycoprotetus. In: Advances in Protein Chemistry, 2: 249. New York: Interscience Publishers, Inc.

55. Meyer, K. (1950) Connective Tisaues. In: Transactions of the First Connective Tisene Conference. New York, Josiah Macy, Ir. Foundation.

56. Meyer, K. and Chaffee, E. (1941L The Mucopolysaccharides of Fuman Sktn. J. Biol. Chem. 138: 491.

57. Meyer, K. and Palmer, J. W. (1934) The Polysaccharide of the Vitreous Bumor. J. Biol. Chem. 107: 629.

58. Meyer, K. and Palmer, J. W. (1936) On Glycoproteins. II The polysaccharides of Vitrous Humor and of Umbilical Cord. J. Biol. Chem. 114: 689 .

59. Meyer, K. and Rapport, M. M. (1951) The Mucopolysaccharides of the Ground Substance of Connective Tissue. Science 113: 596.

60. Mosbach, E. H. and King, C. G. (1950) Tracer Studies on the Biosynthesis of Glucuronic Acid. Federation Proc. 9: 208. 
61. Ogston, A. and Stanier, J. E. (1950) On the State of Hyalueronic Acid in Synovial Fluid. Blochem. J. 46: 346.

62. Pearce, R. H. and Watson, E. M. (1949) The Mucopolysaccharides of Human Skin. Cnad. J. Research (sec. E.) 27: 43.

63. P earse, A. G. E. (1960) Histochemistry--Theoretical and Applied. Little Brown and Co., Boston, Second Edition.

64. Pitt-Rivers, $R$. (1960) Some Factors that Affect Thyroid Hormone Symthesis. Am. N. Y. Acad. Sct. 86: 362.

65. Robb-Smith, A. H. T. (1957) What is Reticultn? In Council for international Organization of Medical Sciences. "Symposium on Connecttve Tissue". London: Blackwell. p., l77.

66. Roche, J., Michel, R. (1960) On the Peripheral Metabolism of Thyrotd Hormones. Amen. N. Y. Acad. Sci. 86: 454.

67. Ropes, M. W., et al. (1947) Sunovial Fluid Mucin. Acta Med. Scandinav. (suppl.) 196: 700.

68. Rose, S.. Nelson, J., Bradley, T. R. (1960) Regulation of TSH Release. Am. N. Y. Acad. Sct. 86: 647.

69. Foseman, S. et al. (1953) The Blosynthesis of Hyaluronic Acid by Group A Streptococcus. I. Utilization of $1-C^{14}$ - glucose, J. Biol. Chem. 203: 213.

70. Rothman, S. (1961) Physiology and Blochemistry of the Skin. The University of Chicago Press. Chicago, Iltinois. (Thtrd Printing).

71. Schultz-Haudt, S. D. (1958) Observations on the Acid Mucopolysaccharides of Human Gingtva. Odont. Tskr. 66: 3.

72. Slack, H. G. B. (1959) Some Notes on the Composition and Metabolism of Connective Tissue. Am. J. Med. 26: 113.

73. Stacey, M. (1946) The Chemistry of Mucopolysaccharides and Mucoprotetns. In Advances in Carbohydrate Chemistry. 2: 161. New York: Interscience Publisher. 
74. Sylven, B. (1954) Metachromatic Dye-Substrate Interactions. Quart. Jour. of Microscop. Sct. 95: 327.

75. Sylven, B. (1957) On the topographical Cytochemistry of Tissue Mast Cells. in Council for biternational Organizations of Medical Sciences. Connective Tissue Symposium. Springfield, $\mathrm{Ml}$. Charles C. Thomas.

76. Toto, Patrick (1962) Personal Commanication.

77. Watson, E. M., Pearce, R. H. (1949) The Mucopolysacchartdes Content of the Sktn in Localized (Pretibial) Myxcedema. II, Am. J. Clin. Path., 19: 412.

78. Wedumann, J., Stcher, H. (1955) Bome and Bones, p., 231, St. Louis, Second Edition., C. V. Mosby Co.

79. Windrum, G. M., et al. (1955) Constitution of Human Renal Reticulin Brit. J. Exper. Path. 36: 49.

80. Wolbach, S. B. (1953) Experimental Scurvy: Its Employment for Study of Intercellular Substance. Proc. Nutrition Soc. London. 12: 247.

81. Wolbach, S. B. (1933) Controlled Formation of Collagen and Reticulin: Study of Source of intercellular Substance in Recovery from Experimental Scorbutus. Amer. J. Path. 9: 689.

82. Zisktn, D., and Steth. (1942) The Gbugtvae and Oral Mucous Membrane of Monkeys th Experimental Hypothyroidism. J. Dent. Res. 21: 296. 
Fig. 1. Normal rat. Oral Mucosa. Very Light Metachromasia in Connective Tissue. Freeze-drying. Toluidine blue stain, $p H 7 \times 100$

Fig. 2. Thyroidectomized rat. Oral Mucosa. Metachromasia in

Connective Tissue. Freeze-drying. Toluidine blue stain, $p H 7 \times 100$

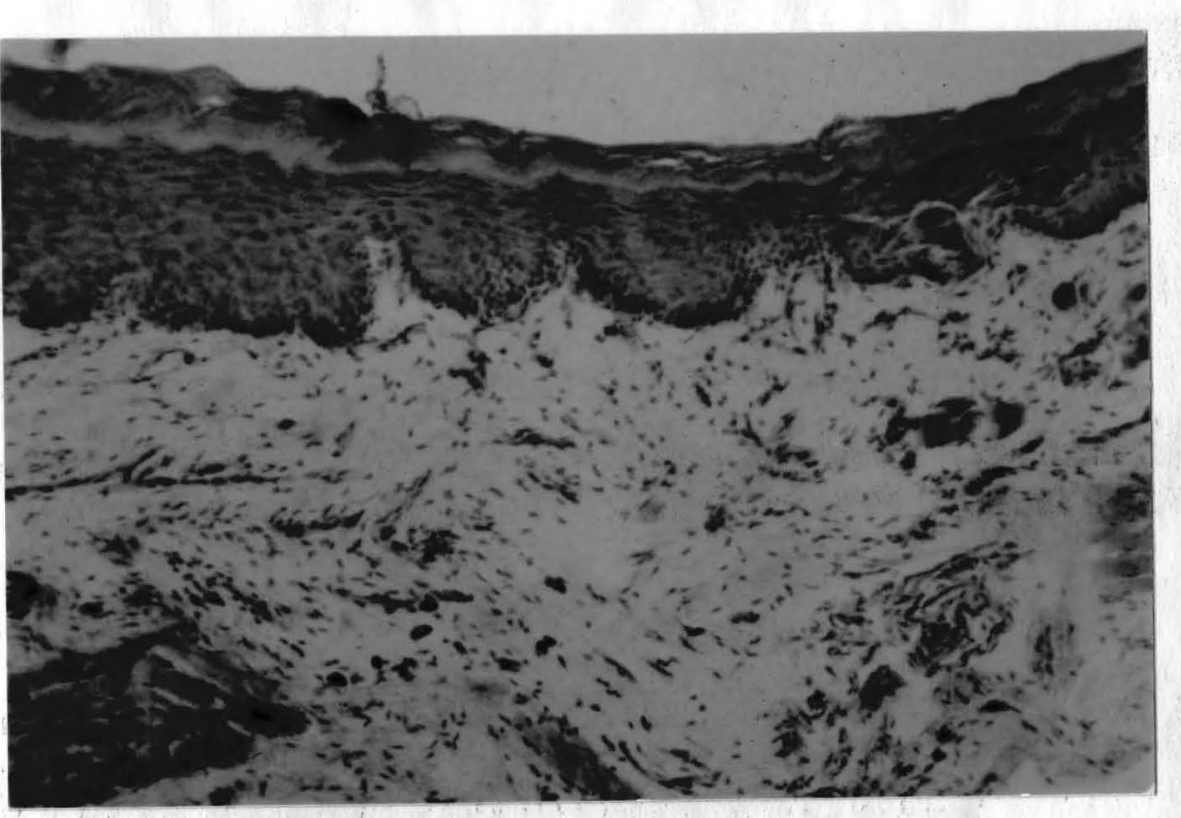

Figure 1.

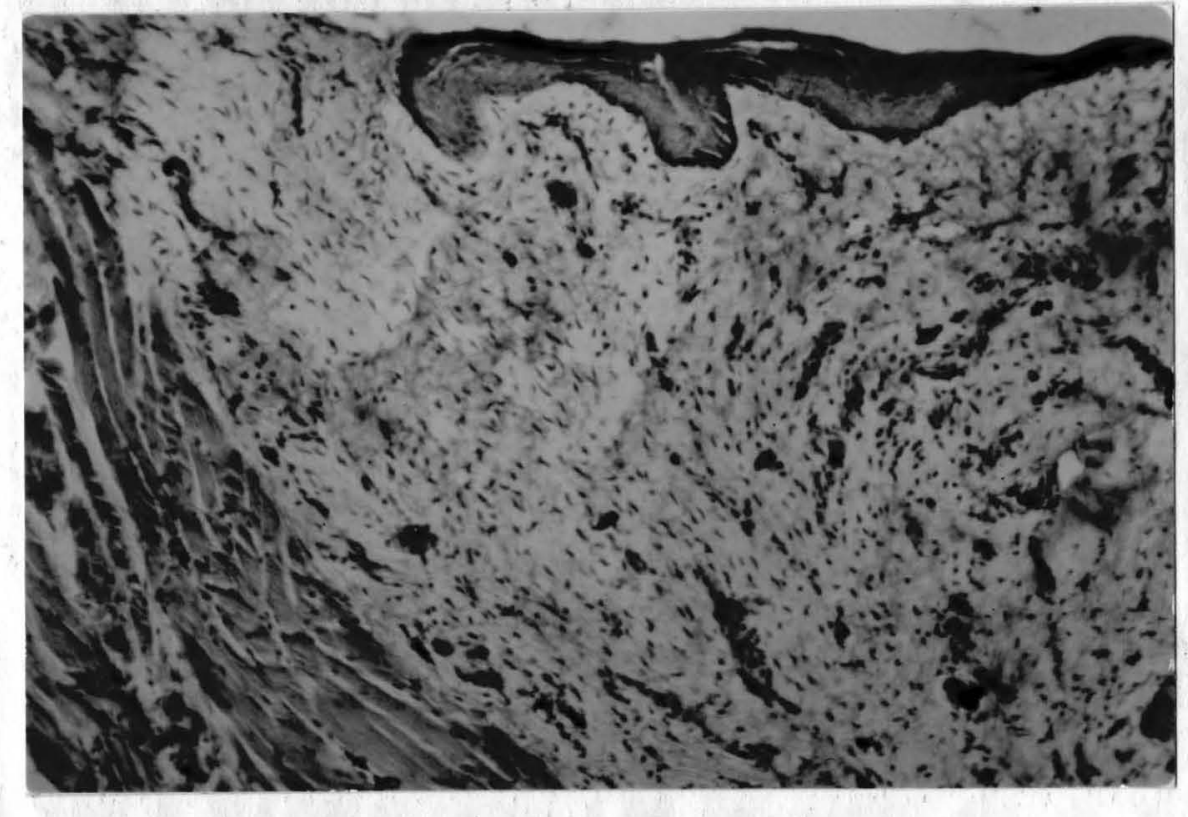

Figure 2. 


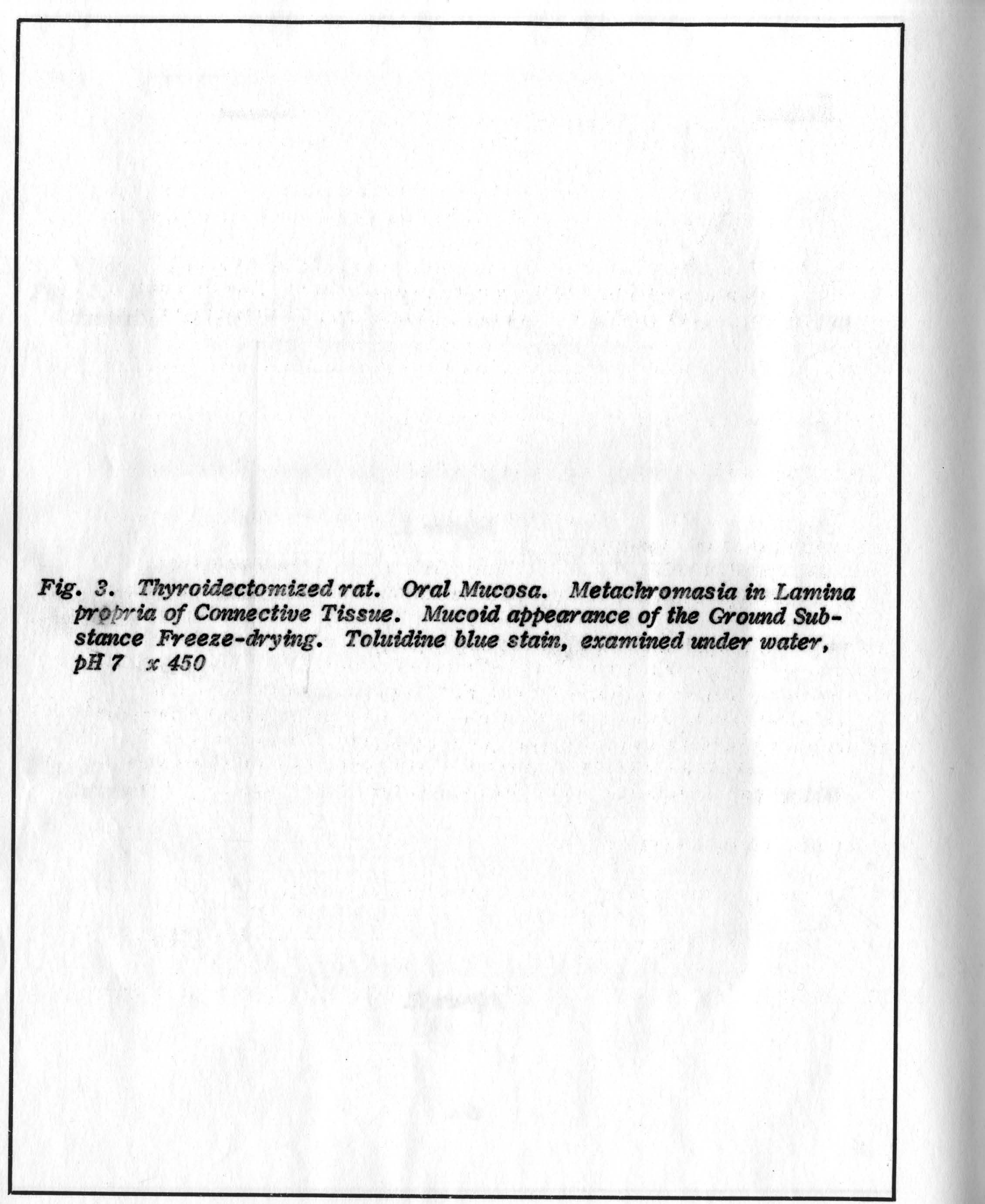


Fig. 4. Thyroidectomized rat. Oral Mucosa. Metachromasia in Lamina Propria of Connective Tissue. Freeze-drying. Sorensen's buffer incubation, three hours. Thionin stain, pH $7 \times 450$

Fig. 5. Thyroidectomized rat. Oral Mucosa. Greatly reduced metachromasia of groumd substance after incubation in testicular hyaluoronidase for three hours, 37 C. Freeze-drying. Thionin stain, PH $7 \times 450$

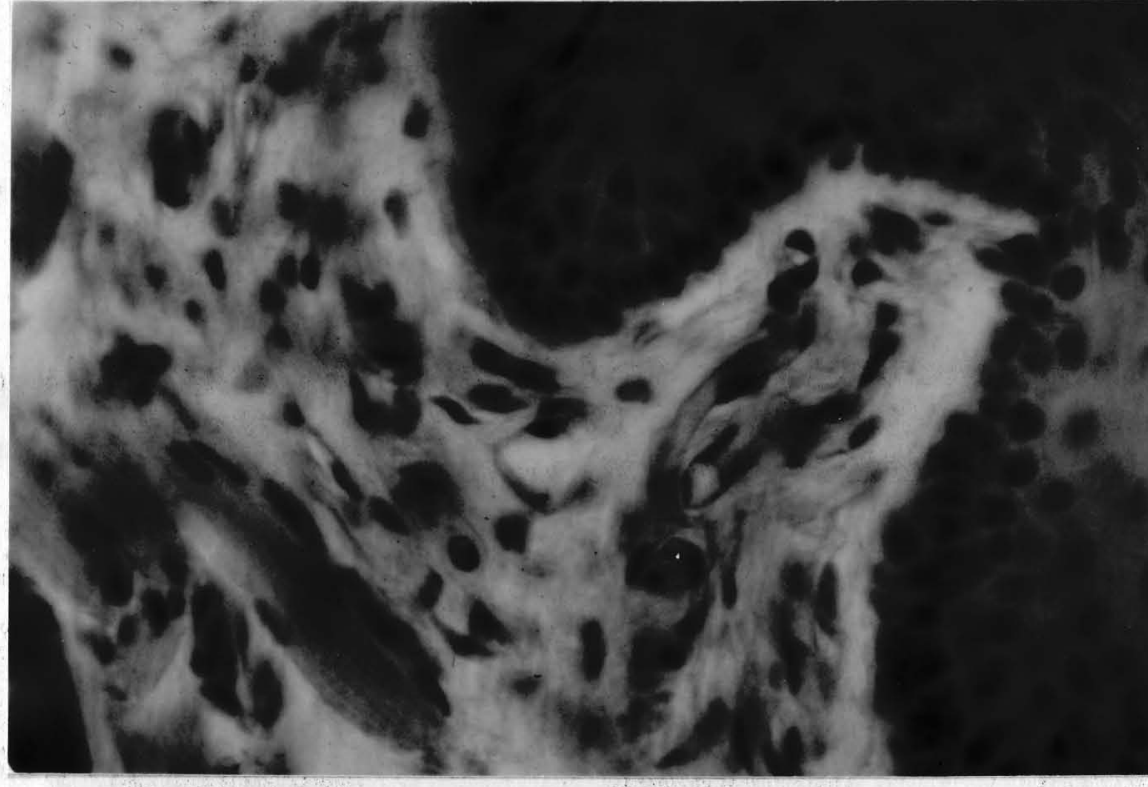

Figure 4.

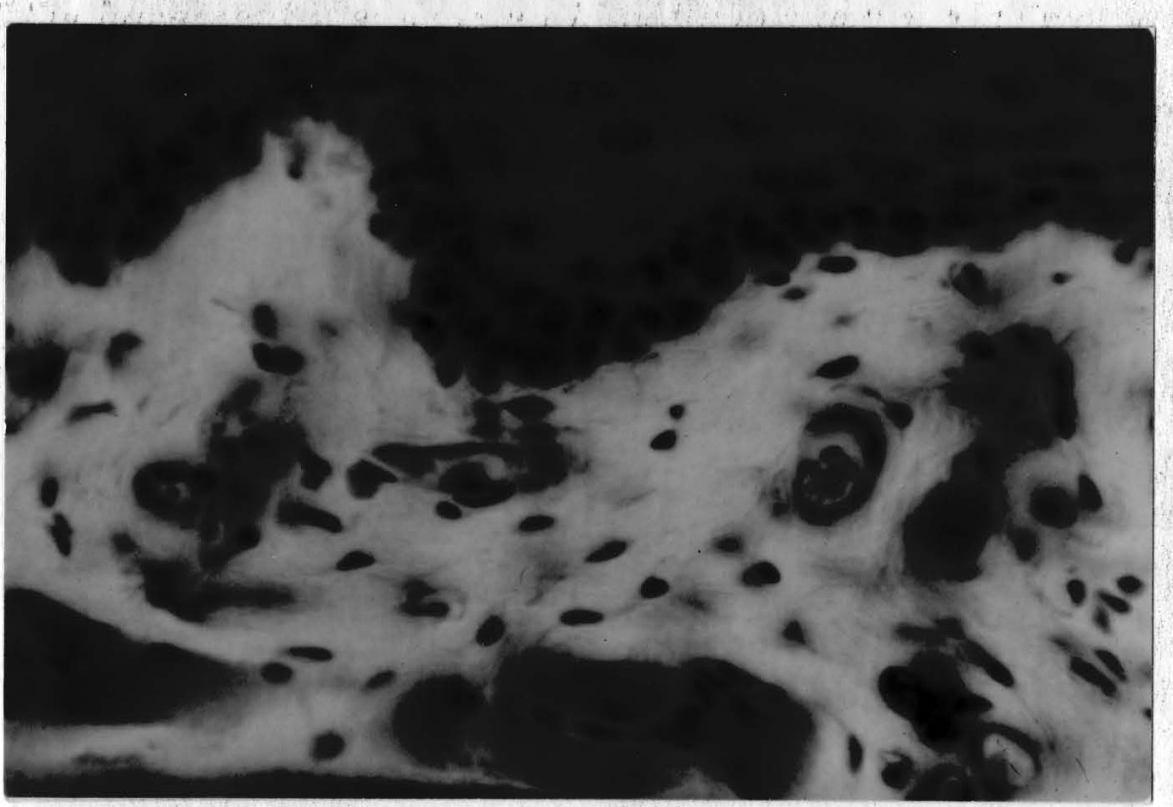

Figure 5. 
Fig. 6. Thyroidectomized rat. Oral Mucosa. Mast cells liberating their granules into the ground substance. Freeze-drying. Toluidine ôlue stain, pHI $7 \times 1000$

Fig. 7. Thyroidectomized rat. Oral mucosa. Mast cell containing PAS positive material in its cytoplasm. Freeze-drying. Periodic-acid Schiff stain. $x 1000$

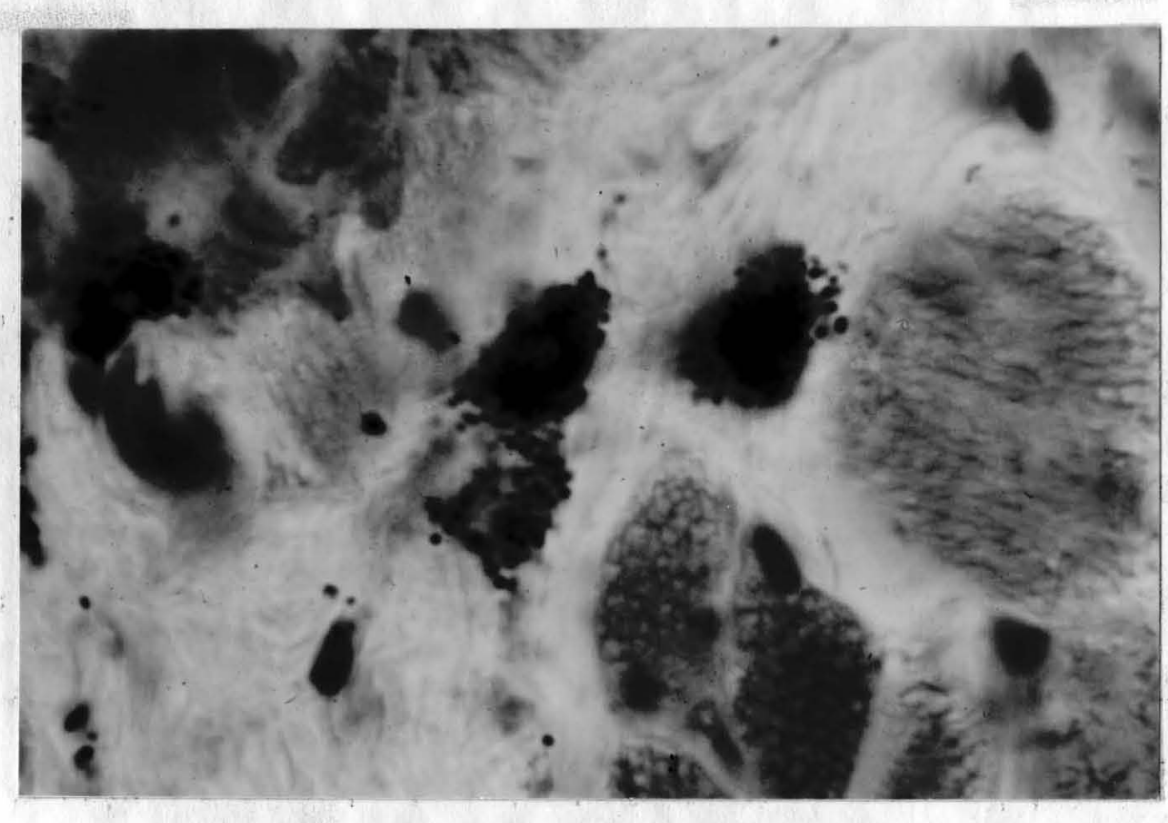

Figure 6.

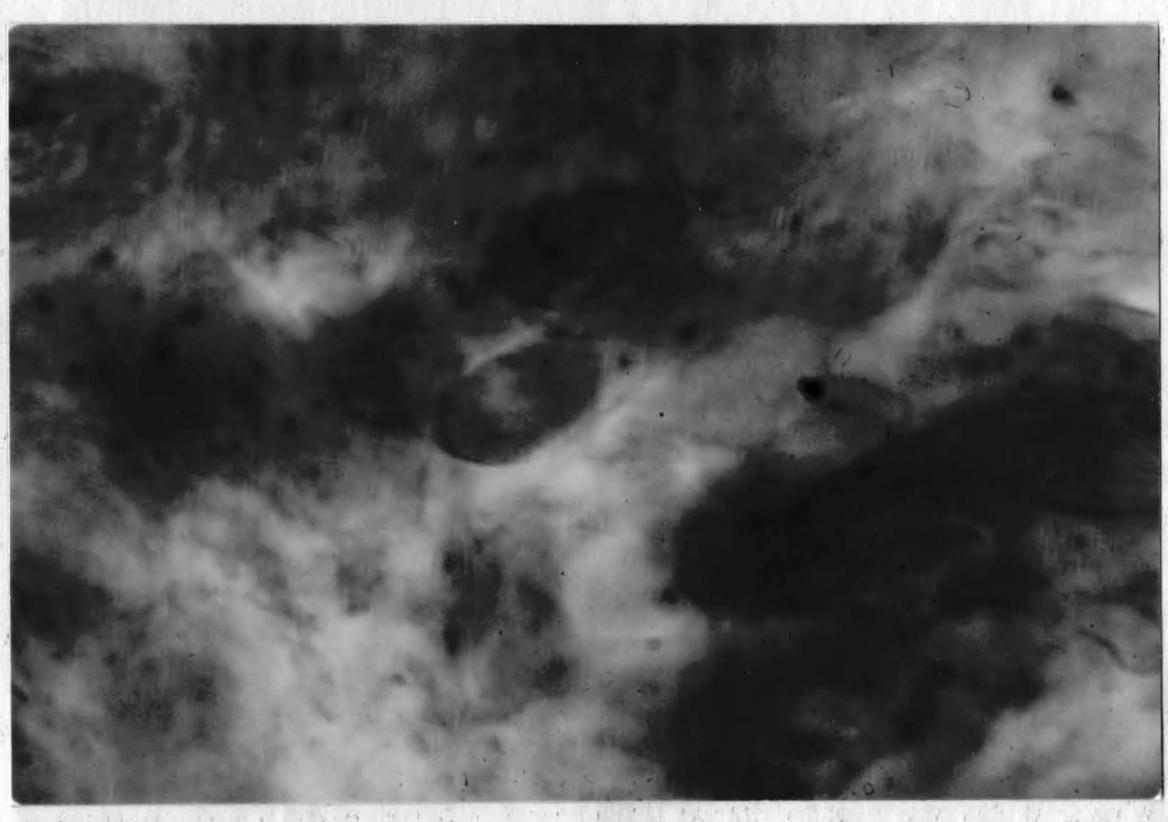

Figure 7. 
Fig. 8. Thyroidectomized rat. Oral Mucosa. Basement membrane along the connective tissue and epithelium junction. Very strong PAS positive reaction. Freeze-drying. Periodic-acid Schiff stain. $x 450$ (Notice the PAS positive reaction in the ICS of the epithelium)

Fig. 9. Thyroidectomized rat. Oral Mucosa. Basement membrane along the opithelium and connective tissue does not show metachromasia.

Freeze-drying. Toluidine blue stain, pH 7 x 1000

(Notice the metachromasia in nuclei and ICS of the epithelium)

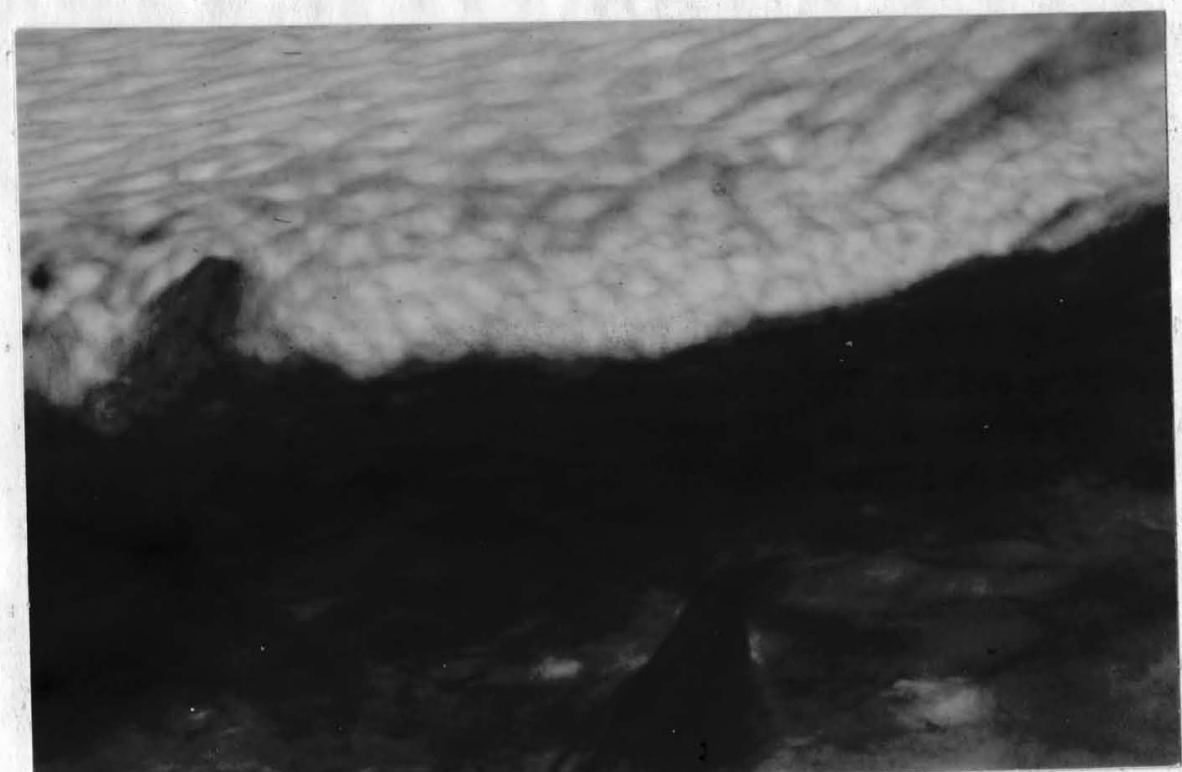

Figuore 8.

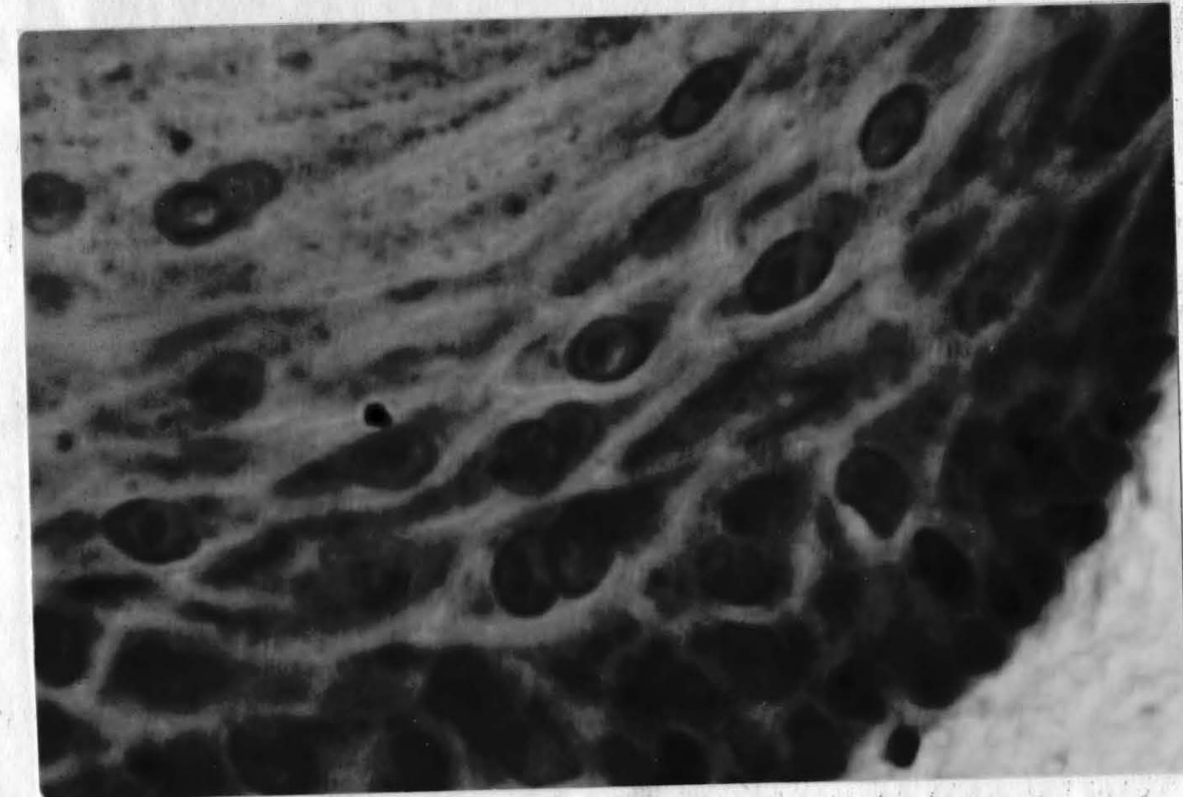

Figure 9. 
Fig. 10. Thyroidectomized rat. Oral Mucosa. Basement membrane along the connective tissue and epithelium junction. Gomori silver impregnation $x 450$ 


\section{APPROVAL SHEET}

The thests submitted by Dr. Rodrtgo Etsemmen Orimas has been read and approved by three members of the Department of Anatomy and Oral Brology.

The fthal copies howe been examined by the director of the thesis and the stemature which appors below verifies the fact that any necessery changes have been twcorporated, and that the thests to now given final approval with reference to content, form, and mecilanical accuracy.

The thesis to therafore accepted in partial fulfultment of the requirements for the dagree of Master of Selence.
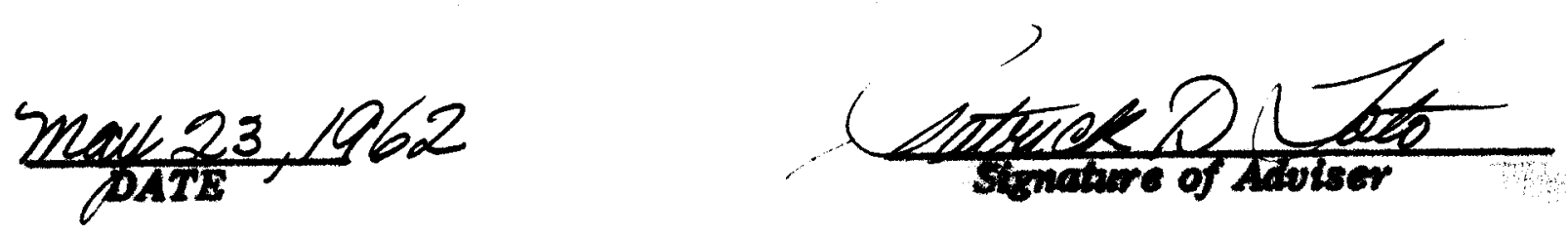